\title{
Spatial dynamics of labor markets in Brazil
}

Kenneth M. Chomitz*, Daniel da Mata†, Alexandre Ywata de Carvalho', João Carlos Magalhães†

* Development Research Group, World Bank

† Directorate of Regional and Urban Studies, Institute of Applied Economic Research (IPEA)

World Bank Policy Research Working Paper 3752, October 2005

The Policy Research Working Paper Series disseminates the findings of work in progress to encourage the exchange of ideas about development issues. An objective of the series is to get the findings out quickly, even if the presentations are less than fully polished. The papers carry the names of the authors and should be cited accordingly. The findings, interpretations, and conclusions expressed in this paper are entirely those of the authors. They do not necessarily represent the view of the World Bank, its Executive Directors, or the countries they represent. Policy Research Working Papers are available online at http:/ / econ.worldbank.org.

\section{Acknowledgments}

This paper is part of a joint research program between the World Bank and the Instituto de Pesquisa Econômica Aplicada (IPEA), Brasília. We are grateful to Jonny Andersson, Piet Buys, George da Guia, Waldir Netto, and Edinaldo Tebaldi, for assistance, advice, data construction, and literature reviews. We have benefited from discussions with Uwe Deichmann, Somik Lall, Maria da Piedade Morais, Marcelo Piancastelli and Vernon Henderson. 


\begin{abstract}
There was substantial spatial variation in labor market outcomes in Brazil over the 1990's. In 2000, about one-fifth of workers lived in apparently economically stagnant municipios where real wages declined but employment increased faster than the national population growth rate. More than one-third lived in apparently dynamic municipios experiencing both real wage growth and faster-than-average employment growth; these areas absorbed more than half of net employment growth over the period. To elucidate this spatial variation, we estimated spatial labor supply and demand equations describing wage and employment changes of Brazilian municípios. We used Conley's spatial GMM technique to allow for instrumental variable estimation in the presence of spatially autocorrelated errors. Chief findings include: a very strong influence of initial workforce educational levels on subsequent wage growth (controlling for possibly confounding variables such as remoteness and climate); evidence of positive spillover effects of ownmunicipio growth onto neighbors' wage and employment levels; an exodus from farming areas; relatively elastic response of wages to an increase in labor supply; and evidence of a local multiplier effect from government transfers.
\end{abstract}

\title{
Resumo
}

O mercado de trabalho brasileiro apresentou uma dinâmica espacial diversa durante a década de 1990. Em 2000, aproximadamente um quinto dos trabalhadores vivia em municípios aparentemente estagnados em termos econômicos, em que os salários reais caíam, mas em que o emprego crescia acima da taxa de crescimento populacional do Brasil. Por outro lado, mais de um terço dos trabalhadores vivia em municípios dinâmicos, com crescimento dos salários reais e crescimento do emprego acima do crescimento populacional brasileiro: essas áreas absorveram mais da metade do crescimento líquido do emprego durante o período. A fim de elucidar essa dinâmica, o presente artigo estimou um modelo espacial de demanda e oferta por trabalho no qual descreve as mudanças no nível de salários e empregos dos municípios. Foi utilizado o método GMM espacial desenvolvido por Conley (1999), que permite o uso de variáveis instrumentais na presença de autocorrelação espacial. Os principais resultados incluem: a influência muito forte do nível educacional inicial da força de trabalho na taxa de crescimento subseqüente dos salários (mesmo após controlar por diversas variáveis, tais como distância e clima); presença de efeitos de transbordamento positivos do crescimento do município sobre os níveis de salário e emprego de seus vizinhos; queda no emprego em atividades rurais; elasticidade na resposta dos salários a um aumento na oferta de trabalho; e presença de efeitos multiplicadores das transferências governamentais. 


\section{Introduction and motivation}

In Brazil, as in other large, heterogeneous countries, there is considerable policy concern about spatial patterns of growth and development. Brazil exhibits large and relatively persistent differentials in income and welfare measures between north and south, and between rural and urban areas. The semi-arid Northeast, in particular, has been an area of concern for at least a century, and still is home to the hemisphere's largest concentration of poor people. At the same time, there has been concern about environmental and social problems associated with rapid expansion of the largest metropolitan areas.

For this reason, there is long-standing interest in finding regional development policies that would stimulate growth in lagging and rural regions. The underlying assumption is that targeting regional development policies on these poorer regions could simultaneously reduce aggregate poverty and regional inequality, and thereby reduce migration to large urban centers. Some of these policies include federal and state incentives for industrial location in lagging areas; provision of basic education; infrastructure development including dams and roads; support for agriculture, including familial agriculture, and community-driven development projects. More recently there has been an interest in a 'territorial approach', which would promote integrated development in a secondary city and its rural hinterland. This approach emphasizes improvement of urban amenities and services as a means of unlocking local growth.

The impacts of these approaches have not been rigorously examined. Indeed, many of the underlying assumptions are open to debate. Do we know how to boost the productivity of secondary cities? Does a thriving secondary city stimulate growth in its surroundings - or displace that growth? Are local investments reflected in higher local wages, or in higher employment? Are there persistent differences in returns to investment in large vs. small cities, or in high vs. low population density areas, in more or less agroclimatically favored areas?

This paper addresses these issues by modeling wages and labor supply at the município ${ }^{1}$ level. In contrast to the more familiar Barro-style growth models, such as in Barro and Sala-i-Martin (1991), the proposed models focus on the role of policy and local social and environmental assets in shaping labor incomes and net migration across the landscape. Working in a spatial econometric framework, we allow for spatial spillovers and for spatial autocorrelation of unobserved variables.

The plan of the paper is as follows. The second part of this paper reviews trends in regional growth in Brazil and reviews policies that have tried to reduce regional inequalities. The third section reviews the literature on income, wage, and employment growth at the subnational level. This leads to specification of a simple labor demandsupply model. Next, we describe the data and the econometric specification employed. The final sections present results, discussion, and conclusions.

\footnotetext{
${ }^{1}$ The município is roughly equivalent to a US county: the administrative level beneath the state. They are extremely heterogeneous in size, ranging in population from a few hundred to over 8 million. There are currently 5561 municípios in Brazil.
} 


\section{Issues in Brazilian growth}

Brazil is a country with large disparities in income between individuals and at all geographical scales. Much though not all of this inequality stems from inequalities between regions. In particular, the Northeast of the country has historically lagged behind the South and Southeast, where much of the Brazilian economy is concentrated. The income per capita ratio of the richest State and the poorest one was 8.9 in 1960 and 6.2 in 1996. (Azzoni et al., 2000). The 2000 figure was 7.7. This analysis can be extended also to social indicators such as the human development index (HDI). Out of the 10 cities with the worst HDI in Brazil, seven were in the Northeast in 1991 and eight in $2000 .^{2}$ Within regions, there are substantial inequalities between states and among municípios. And even within municípios there are substantial inequalities, with many indigent people living in the municipíos with the highest mean income.

Particular attention has been focused on longstanding regional inequalities, especially between the Northeast and the rest of the country. There is some evidence of convergence in incomes between states over the periods 1939-1985 (Azzoni 2001) and 1970-1985 (Ferreira and Diniz 1995). However, several papers find evidence that this convergence process stalled after 1985, with one or two groups of poor states tending towards a lower-income equilibrium than the richer part of Brazil. (Azzoni 2001; Ferreira 1998; Pontual e Porto Júnior 2000). Azzoni et. al. (2000) estimated traditional regressions of growth with microdata for 19 Brazilians states. They divided their dataset in cohorts and used a large list of variables as determinants of growth, including microdata from PNAD - National Household Survey. The results suggest that per capita incomes of the Brazilian states have already converged to their steady-state level and that they will remain unaltered due to huge educational and geographic differences between the states.

What accounts for these disparities? The North and Northeast of the country lag far behind other regions in quantity and quality of education, and these differentials are strongly correlated with differences in labor income, as human capital theory would suggest (Fiess and Werner 2004). However, education and other observable individual characteristics do not fully explain interregional wage and income differentials. Azzoni e Santos (2002) compared the differences in salary in the 10 largest Brazilian metropolitan areas in 1992, 1995 and 1997. Those salary differences remained significant even after controlling for cost of living measures, the traits of the workers (education, age, sex, race and family position) and the traits of their jobs (occupational position, sector and experience). Fiess and Werner (2004) estimated mover/stayer models of wage and migration. They found that low-education Northeasterners could boost their wages by $80 \%$ through migration; the differential declined with higher levels of education. Evidently, judging from the evidence cited above, the substantial degree of interregional migration is not sufficient to induce convergence between the regions.

Brazilian policy has been concerned with reducing interregional inequalities. Best known, perhaps, are the national programs of tax and fiscal incentives, including the Constitutional Funds, subsidized loans from development banks including BNDES and BNB, the Zona Franca of Manaus, and FINOR. Some programs were explicitly targeted on poor regions. For instance, Projeto Alvorada sought to provide education and other services to states (and later microregions) with below-median HDI. Individual states use fiscal incentives to influence intrastate location of industrial firms, but the scope and impact of these programs is not comprehensively known. Other programs

\footnotetext{
2 The others were in the North Region.
} 
were not explicitly regional in intent but may nonetheless have had differential regional impacts. Possibly the most important of these is transport. Brazil's transport infrastructure has improved markedly over the last 40 years (Castro 2003). Lall, Funderberg, and Yepes (2005) show that the productivity of manufacturing firms tends to increase with decreasing transport cost to São Paulo, the country's industrial hub. On the other hand, increased access to São Paulo or other metropolitan centers exposes local firms to increased competition from possibly more efficient firms, so the net effect on regional development is indeterminant. Another important policy affecting regional development was EMBRAPA's development of soybean varieties adapted to low latitudes. This innovation was responsible for the massive expansion of soybean cultivation in the Center West after 1970.

There is widespread enthusiasm in Brasil and throughout Latin America for a new, more fine-grained approach to regional development, 'territorial development.' This approach has many of the elements of the growth poles approach that was popular 30 or 40 years ago. Although there are differing interpretations of this concept, it typically focuses on spurring the development of secondary cities as means of stimulating growth in the surrounding area.

For instance, the states of Ceará and Bahia have devoted considerable analysis and planning to articulating detailed visions of territorial development. Both have adopted territorial development strategies emphasizing the development of secondary or strategic cities as cornerstones of regional growth (Bar-el et al 2002; Governo do Estado da Bahia, 2003). Cearás visions of regional development provide concrete examples of the territorial development approach (Secretaria de desenvolvimento Local e Regional 2004), emphasizing improvement of road and air transport, improvement of basic services including sanitation and communication, development of cultural and natural resources as the basis of a tourism industry, support services to agriculture, including sheep and goats, and expansion of irrigated fruiticulture.

To sum up, interregional inequalities are a long-standing concern in Brazil. Principal strategies for combating these inequalities have been the use of explicit or tax subsidies to attract industrial firms; improvements in transport and urban amenities; and investments in human capital. These strategies are implicitly assumed to boost wages and thereby to reduce poverty and interregional inequality. However, quantitative estimates of these impacts are lacking.

\section{Literature review}

There has been an explosion in the production of subnational growth models. Most of these are in the tradition of Barro and Sala-i-Martin (1991), and are concerned with the detection of convergence in per capita income levels or growth rates across the subnational units. The models are sparsely parameterized; growth is represented primarily as a function of prior-period per capita income, possibly with some structural conditioning variables. This approach is not ideal for the present purpose because there is little scope for exploring the impact of policy interventions such as infrastructure investments. When policy-relevant variables are included as conditioning factors, they are constrained to affect growth rates rather than income or employment levels.

More apt for our purposes are the models applied by Fan and co-authors to India and China (see Fan, Zhang, and Zhang (2002), Fan Hazell and Haque (2000), Fan and 
Chan-Kang (2004)). These papers seek to measure the marginal impact of government investments on income and on poverty, with particular attention to the returns to investment in less-favored areas. In Fan, Zhang, and Zhang (2000), for instance, a provincial production function relates agricultural GDP per capita to land per worker, agricultural capital per worker, agroclimate, and infrastructure stock. However, land per worker and capital per worker are taken to be fixed and exogenous. There is no allowance for interprovincial labor mobility.

While the assumption of immobile labor may be acceptable when considering large provinces, and for countries where there are strong legal or social barriers to migration, it is less apt for Brazilian municípios. Here, labor mobility may play an important role in understanding differential spatial patterns of development. As Pritchett (2004) points out, in the absence of barriers to migration, one would expect local market or technology shocks to be reflected in labor movements rather than wage changes. Hence local investments may be effective in alleviating poverty even if they do not result in a perceptible change in wages. It is possible, instead, that they attract labor from lower wage areas. In this case, regional interventions would be effective in alleviating poverty but not in reducing measured interregional inequalities.

Araujo, de Janvry, and Sadoulet (2004) present a município-level, spatial model of employment growth in Mexico that is the closest precursor of the current paper. They relate growth in employment over 1990-2000 to 1990 values of employment, proximity to urban centers and other employment nodes, geographic characteristics, and wages, and use spatial econometric techniques. They find that rural employment growth in both services and manufacturing is inversely related to distance to the nearest urban center.

\section{Approach: the spatial dynamic of labor supply and demand}

We model subnational development through a spatially disaggregate model of labor market dynamics. The labor market approach has several advantages for our purposes over Barro-type growth models. First, our model offers potentially better insight into poverty alleviation strategies because it looks at wages rather than GDP/capita - an important consideration when wealth is unequally distributed. Second, while the growth models use regions as units of concern, looking only at mean income levels, the labor market approach looks also at employment. It is entirely possible for regional mean incomes to diverge even while incomes of individuals increase, if employment expands faster in higher-wage markets. Models focused only on mean income may entirely overlook such an outcome. Third, growth models typically employ a sparse set of policy-relevant variables. Here we examine the impact of a range of policy levers, including education, infrastructure, and transfers, while allowing for differential effects in regions with different agroclimatic conditions. Finally, our fine-scaled geographic approach facilitates an examination of local growth spillovers, allowing examination of the premises of territorial development policies.

\section{A spatial model of labor and demand}

These considerations motivate a labor supply/demand model, which examines the determinants of labor income and employment growth at the município level. It is important to recall that labor income, and indeed municipal household income, does not 
necessarily track municipal GDP. For instance, some rural municípios may be dominated by capital-intensive farming systems, whose value-added accrues to absentee landlords. Nonetheless, a focus on labor income is justified by a policy concern with spatial aspects of poverty and welfare. Our results can be compared with those of growth regressions by taking wage growth as a proxy for productivity growth and employment as a proxy for município size.

Let each município i have a production function $f\left(K_{a}, L, E d u c ; A\right)$ for a composite output, where $\mathrm{K}$ is a vector representing industrial and agricultural capital, including land); $\mathrm{L}$ is the number of workers; Educ is a vector measure of the quantity and quality of worker education; $A$ is a vector of productivity shifters, which include transport connectivity to markets, local governance quality, and agroclimate. These are typically time-invariant or change slowly over time. The município faces a price which is a function $\mathrm{P}(\mathrm{MP}, \mathrm{GT})$ of local market potential or demand and of government transfers to individuals. The latter, which largely represent rural pensions, are locally important in some areas and may drive demand for local nontradeable services. MP is operationalized as an inverse-distance-weighted function of the total incomes of neighboring municipalities. A labor demand equation expresses the wage rate as the value of the marginal product:

$$
w=P(M P, G T)(\partial f / \partial L)
$$

Differencing over time, using a convenient ln-linear approximation, we have:

$\Delta \ln w=X \beta_{0}+\beta_{1} \Delta \ln L+\beta_{2} \Delta \ln M P+\beta_{3} \Delta \ln G T+\beta_{4} \Delta \ln K+\beta_{5} \Delta$ Education

where $X$ is a set of determinants of the rate of growth of productivity, and Education is the quality-adjusted mean educational level of the work force. We assume that wages adjust rapidly to changes in capital, labor supply, and prices.

We assume, in contrast, that capital and labor adjust relatively slowly to changes across the landscape, in relative wages and returns to capital. Thus we model the change labor supply from $t-1$ to $t$ as a function of local wages, local amenities, and competing neighborhood wages in period $t-1$ :

$$
\Delta \ln L=\Delta \ln L\left(\ln w_{t-1}, \ln E W F_{t-1}, \ln M P_{t-1}, A M E N I T I E S_{t-1}, A G R O C L I M A T E\right)
$$

where $E W F_{t-1}$ is the relative size of the cohort, in period $\mathrm{t}-1$, which will enter the labor force by period t. We hypothesize that the labor force increases more rapidly when initial local wages are high, reflecting long-distance migration ${ }^{3}$. Holding constant wages within the município, employment is expected to grow less rapidly, the more rapid the change in local market potential, because local labor may be relatively easily attracted to

\footnotetext{
${ }^{3}$ Ideally the wage measure should be adjusted for spatial differentials in cost of living; unfortunately spatial price indexes are not available, so we use nominal wages, inflation-adjusted nationally over time.
} 
neighboring dynamic areas. Agroclimate is postulated as an exogenous determinant of employment growth. This allows for the possibility that agricultural labor is shifting between agroclimatic zones - and perhaps, especially, out of less favorable zones - in response to changing agricultural market conditions.

We model capital investment as

$$
\Delta \ln K=\Delta \ln K\left(\text { MARKETACCESS }_{t-1}, \text { GOVERNANCE, AGROCLIMATE, } \Delta \ln M P\right)
$$

Better market access (measured by lower transport costs to São Paulo and to the nearest state capital) is associated with lower price levels and hence higher returns to capital. Better local government is expected to increase the município's attractiveness for investment. Increases in the market potential indicate location near a dynamic region; this potentially endogenous instrument must however be instrumented.

Because we lack reliable data on capital, we substitute (3) into (1). While we have data on mean years of education of the work force, we lack information on employees' educational quality. Moreover, a dynamic município may experience changes in mean educational level due to compositional effects, depending on the relative educational level of in-migrants, out-migrants, and stayers. Hence we use initial educational level of workforce, and initial educational level of public school teachers (a proxy for local educational quality) in place of educational change in (1). We interpret the result as describing the demand curve while allowing for the endogenous response of capital investment to initial conditions.

\section{Data}

We examined patterns of employment and wage change over the period 19912000. The basic spatial unit of analysis was the município. A complication, however, is that some municípios experience splits over the study period, the total number growing from 4491 to 5507. In complicated cases, two municípios are reorganized into three. To address this problem, we merged municípios into 4267 Minimum Comparable Areas (MCAs) - consisting of sets of one to three municípios whose borders were constant over the study period.

Much of the data stem from the Brazilian Population Censuses of 1991 and $2000{ }^{4}$ The key variables of interest were employment: total number of people reporting any employment and wage: reported labor income divided by the number of workers. Self-employed workers and farmers are counted as workers, and their earnings are counted as labor income. Table 6 gives the sources and definitions of variables employed in this paper. Table 7 provides summary statistics for these variables. Some of them are mapped in the appendix.

A unique feature of this analysis is the use of market potential and related variables. Market potential for a target MCA i is defined as the weighted sum of personal incomes of all other MCAs, where the weight is a decreasing exponential of distance to the target município:

\footnotetext{
${ }^{4}$ To be precise, they stem from the 12,5\% Census sample of 1991 and 5\% Census sample of 2000. Both samples represent município level data.
} 


$$
M P_{i}=\sum_{j \neq i} \exp \left(-d_{i j}^{2} / 2 \alpha^{2}\right)
$$

where $d_{i j}$ is the great-circle distance between the centroids of $i$ and $j$ in kilometers, and $\alpha$ is the inflection point in kilometers, here set to 25 . The effective radius of influence is about 50 kilometers. Analogous expressions were used to derive distance-weighted measures of population and of mean educational level, again excluding values from the target município. These variables were used as instruments for market potential.

The results reported here are divided into three categories: Brazil, nonmetropolitan Brazil and the latter without the North region. The difference between the first two categories is based on IPEA, IBGE and UNICAMP (2002). That work makes a comprehensive classification of Brazilian urban agglomerations. We used the municípios that belong to urban agglomeration only in the first category.

\section{Spatial patterns of labor dynamics}

Figure 1 and tables 1-5 illustrate the geographic diversity of Brazil's labor market dynamics over the period 1991-2000, a diversity we seek to explain. We classify MCAs into four categories, depending on whether wage growth was positive or negative, and whether employment growth was above or below the mean national population growth rate

The most striking point evident from the maps is the general decline in real wages in the North and Northeast, and general increase elsewhere in the country. However, because population density varies tremendously across Brazil (see figure 2), maps can give a misleading impression of the number of people who fall into the labor dynamics categories. Tables 1-5, and population density maps (figure 2), provide a more accurate representation of population breakdowns.

The main point of the tables is spatial divergence and heterogeneity in experience. Areas in which employment grew rapidly but real wages declined $(\mathrm{E}+\mathrm{W}-$, shown in yellow in figure 1) can be thought of as areas of economic stagnation. Here, labor demand failed to keep up with the growth of supply. This may well reflect natural increase; the mean total fertility rate for the E+W- areas was 3.78 in 1991, far above the other three categories, and the proportion of immigrants in the 2000 population was substantially lower than for the $\mathrm{E}+\mathrm{W}+$ category. By 2000 , about $22 \%$ of employed workers lived in the stagnant $\mathrm{E}+\mathrm{W}$ - areas. They account for a particularly large share of population in the North and Northeast (figure 3).

A set of dynamic areas with both increasing wage growth and rapidly increasing employment $(\mathrm{W}+\mathrm{E}+)$ absorbed more than half of the country's net increase in employment, ending up with $36 \%$ of Brazilian employment in 2000 . Such an outcome may reflect a dynamic local economy, with a relative shift outward in the labor demand curve. Although the 1991 total fertility rate for these MCAs was a full point lower than that of the E+W-areas, the dynamic areas had a substantial higher proportion of recent immigrants in 2000; this suggests that these regions are growing via immigration, presumably drawn by economic opportunity. Most of the $\mathrm{E}+\mathrm{W}+$ population is urban. Among the regions, the Center West has by far the largest proportion of people living in E+W + AMCs, nearly $70 \%$. The Northeast has the lowest proportion, just $10 \%$. 
Tables 4 and 5 show also that about two-thirds of employment is in the metropolitan agglomerations. Over the nine year interval, employment grew a total of $15 \%$ in the nonmetropolitan areas vs $20 \%$ in the metropolitan areas. Dynamic areas $(\mathrm{W}+\mathrm{E}+)$ account for a much larger share of employment in metropolitan areas than in nonmetropolitan areas. Stagnant (W-E+) areas are much more prevalent in the nonmetropolitan areas.

Figure 4 shows an important correlate of wage growth that is associated with the north/south differential. It plots, in $\ln -\ln$ form, the mean educational level of 1991 employees against wage growth over 1991-2000, by MCA. MCAs from the North and Northeast are shown in red; others are in blue ${ }^{5}$. The figure shows that wage growth is strongly and significantly associated with initial educational level. It shows also that a significant disjunction in these variables between north and south. Northern and northeastern MCAs have markedly lower educational levels, and markedly lower wage growth.

Is this a causal relationship? Places with higher human capital may also have higher levels of social capital and may therefore be better able to attract further investment in human and physical capital, and to boost local productivity. On the other hand, causality may go in the opposite direction. Places with inherent social capital or other local advantages may experience both more rapid growth and greater investments in education. The labor supply and demand equations estimated below attempt to hold constant other characteristics that might be associated with educational levels.

\section{Econometric model}

We estimate independent, ln-linear approximations to the wage (labor demand) equation of (3) substituted into (1), and the labor supply equation (2). Endogenous variables are instrumented with time-lagged or space-lagged exogenous determinants. In the wage equation, $\Delta \operatorname{lnL}$ is instrumented with lagged demographic determinants of labor force growth; the exclusion of these variables from the wage equation identifies it. The labor supply equation is identified, more tenuously, via the exclusion of the market access variables and the government transfer variables ${ }^{6}$, and by the use of initial period wage rather than wage change. Table 6 lists the instruments for each endogenous variable.

Finally, a key issue in estimation is the likelihood of spatial autocorrelation of unobserved variables. Failure to account for this autocorrelation could lead to inaccurate estimates of standard errors. To address this issue, we use the GMM technique of Conley (1999) (as did Araujo, de Janvry and Sadoulet 2004 and Baicker 2005). In contrast to the more standard spatial econometric approach using a weight matrix, Conley's nonparametric technique requires only that users locate data points in a real or virtual space. Users specify a cutoff distance beyond which spatial autocorrelation is thought to be unimportant. For our analysis we use the latitude and longitude of the MCA centroid to locate the data points. This technique is attractive because it is computationally feasible for large numbers of observations; allows for the use of

\footnotetext{
${ }^{5}$ Readers are again referred to the color pdf version of this paper. The figure shows that the northeastern and northern observations are clustered in the lower left of the diagram.

${ }^{6}$ We assume that the transfers go mostly to old-age pensioners and thus do not affect labor supply
} 
instrumental variables; and is robust to misspecification of the degree of autocorrelation among neighboring observations. Carvalho, da Mata and Chomitz (2005) discuss and assess the technique in detail.

\section{Results}

We present the results for three samples. The model was intended to focus on nonmetropolitan Brazil, under the assumption that growth dynamics of these regions differ substantially from those of metropolitan areas. However, we test that assumption by running a regression also for the entire country. Finally, we run a model for nonmetropolitan regions outside the North. Many Northern MCAs have very small and volatile work forces, and Amazonian frontier regions may have very distinctive patterns of employment growth. The regression results are in tables 8-10.

For each model we present the results for both 2SLS and spatial GMM specifications. As a sensitivity test, we ran the GMM regressions using different cutoffs for spatial autocorrelation: $0.5,1.0$ and 2.0 degrees. $^{7}$

For the Brazil-wide demand regressions, there is reasonable agreement among the specifications on a number of variables. All four variants find that initial educational level is significantly related to wage growth, other things constant, and the estimated coefficient is stable at about 0.06 . This implies that an increase of one year in the initial mean educational level of the workforce is associated with a $6 \%$ increase in mean wages over the nine year period. Higher initial teacher qualification does not have a similar effect. This may reflect collinearity with years of education combined with nonlinearity in the relationship. In all specifications, rainfall is statistically significant and quantitatively extremely important. A $500 \mathrm{~mm}$ increase in annual rainfall is associated with a nine-year increase of $30 \%$ or more in wages. It is possible that this variable is capturing other aspects of inter-regional variation.

In all four specifications, delta $\ln$ employment is statistically significant. The estimated demand elasticity of wages with respect to labor increases in absolute magnitude with increasing cutoff distance (where we treat 2SLS as having a cutoff of 0 ). The elasticity is -0.49 in the 2SLS specification, increasing to -0.89 for a cutoff of 2.0 .

All four specifications show significant impact of growth of market potential. The elasticity of wage growth with respect to market potential increases with cutoff distance, increasing from 0.55 in 2SLS to 1.30 in the cutoff 2 case. Coefficients of this magnitude suggest either very substantial local spillovers, or failures of the instrumental variables to control for unmeasured growth effects common to the MCA and its neighbors.

Other variables of interest are statistically significant in the 2SLS specification, but less so in the spatial GMMs. On theoretical and empirical grounds, we expected capital investment, and therefore wage growth, to decline with increasing transport costs to São Paulo and to the nearest state capital. However, in the 2SLS specification these variables, though statistically significant, were negligible in absolute magnitude. Significance and magnitude declined with increasing cutoffs. The change in government transfer payments was statistically significant in the 2SLS and the cutoff $=0.5$ specifications, with coefficients of about 0.3 and 0.2 respectively. This suggests marked

\footnotetext{
${ }^{7}$ Each unit in the cutoff measure is equivalent to a hundred kilometers.
} 
local multiplier effects of such transfers. However, the variable declined in magnitude and significance at higher cutoffs. Finally a rough proxy for quality of municipal governance - an indicator of whether the municipal financial accounts had been computerized by 1999 -- had a modest effect under 2SLS, but not under the GMM specifications.

We turn now to the countrywide labor supply equation. Here all four specifications show strong agreement on the coefficients and significance of number of variables, although standard errors increase with the cutoff levels. First we consider wage variables. Labor supply has an elasticity of about 0.18 with respect to the 1991 wage level, so that higher initial wages are associated with a mildly faster rate of employment growth. Although we expected the change in $\ln$ market potential to have a negative coefficient, it was robustly determined at about 0.23 . This suggests that location in a booming region has spillovers on labor supply as well as demand.

Consider next the impact of initial demographic and agroclimatic conditions. The 1991 ratio of workforce entrants to working age population was also robust and highly significant, as expected. Perhaps most striking, all the specifications found a very strong negative association between the proportion of employment in farming in 1991, and subsequent employment growth. This strongly suggests an exodus from farming regions. Lower temperature and higher precipitation are associated with faster employment growth. The first and third principal components of rainfall ${ }^{8}$, which capture variation in annual seasonality of rainfall, are also significant though difficult to interpret directly. Very small MCAs showed more rapid growth than very large ones, all else equal.

Two demographic variables showed robust effects contrary to our expectations. We had expected the initial labor force participation rate to be negatively correlated with subsequent employment growth, on the argument that places which had already experienced growth in female labor force participation would have less scope for further employment expansion. But in fact labor force participation was strongly positively associated with employment growth. We expected also that places with high native proportion of population (i.e. born in the município of current residence) represented areas that had barriers to outmigration or were unattractive to in-migration, and hence predicted lower employment growth rates. However, the coefficient on this variable was positive, significant and robust.

Finally, the regression includes a few variables intended to capture the impact of local amenities on attracting and retaining labor. Initial homicides per capita had a negative effect on employment growth, though the significance of this coefficient declined with higher cutoffs. A one standard deviation increase in homicides corresponded roughly to a $4 \%$ decrease in employment growth over the nine year period. The initial level of teacher qualifications had a negative effect on employment growth, contrary to expectations, but the effect was of negligible magnitude.

The demand-side results for the nonmetropolitan sample (table 5) are quite similar to those for the nationwide sample, despite the huge disparity in MCA size. The coefficients on education and rainfall are of about the same magnitude as before. The labor elasticity coefficient is about -0.74 and significant in all the GMM specifications, slightly more negative than the 2SLS specification. The coefficient of the change in market potential is also relatively consistent across the GMM specifications, with an

\footnotetext{
${ }^{8}$ Calculated from the vector of the 12 monthly averages of precipitation. The second principal component is nearly collinear with total precipitation.
} 
elasticity of about 0.6. In contrast to the nationwide sample, the coefficient on government transfers here stays robust across the GMM specifications, at about 0.16. The coefficients on transport cost are here more significant, though still negligible in magnitude. These results (including the effect of rainfall) are essentially unchanged when the North region is excluded.

The supply-side results for the nonmetropolitan samples also are very similar to the nationwide results. The main difference is that the effect of the initial proportion in farming is reduced in magnitude, but it is still quite important quantitatively and statistically. In addition, the initial participation rate is no longer significant in the nonmetropolitan analyses.

A final caution on our results relates to the J-test. For most of the GMM regressions, the test statistic is significant at the $5 \%$ level, which suggests potential problems with the instruments. It is not however significant at that level for the Brazilwide demand regression (cutoff of 2.0) and the nonmetropolitan supply regressions excluding the North (cutoffs of 1.0 and 2.0).

\section{Discussion}

We have found a number of relationships that appear to be robust to different choices of sample and different controls for spatial autocorrelation.

Initial levels of workforce education are strongly related to subsequent wage growth, even after controlling for correlated variables such as remoteness and climate. Note that this is different from the well-known association between education and wage levels; it suggests an accelerator effect, where more-educated regions experience more rapid wage growth. And, the effect is large. In 1991, the mean educational level of workers was 3.9 years for the country as a whole and just 3.6 years for nonmetropolitan regions. The standard deviation for nonmetropolitan regions was 1.32 years. A change of this magnitude was associated with a $8 \%$ increase in wages over 1991-2000.

If confirmed, this a sobering finding from the viewpoint of reducing inter-regional inequalities. It suggests that wages will continue to diverge between the moreeducated south and the less-educated north. And because it takes 40 years to turn over the labor force, it will take a long time for lagging regions to reduce the educational gap with leading ones, even if the former were to make more rapid progress - itself a questionable assumption.

Farming regions are losing employment, or growing more slowly, than other regions. In the nationwide sample, each 10 percentage point increase in the initial proportion of farmers among workers was associated with a 10 to 12 percent decrease in the nineyear rate of employment growth. Even when the sample is restricted to nonmetropolitan areas, this relationship holds, though it is less steep. Further investigation is needed to understand the degree to which this represents 'pull' factors - attraction to growing areas, vs. 'push' factors - e.g. displacement of smallholders by large farming enterprises.

Low rainfall areas lagged other areas in wage and employment growth. These patterns were evident even controlling for remoteness and education, which might be correlated with rainfall.

$W$ ages respond relatively elastically to changes in labor supply. This suggests that in-migration could substantially reduce wages in an MCA with vigorous demand growth; that 
population growth would depress wages in a stagnant MCA; and that outmigration could put upward pressure on wages for those left behind in declining MCAs. The supply-elasticity of wages is important to keep in mind when evaluating regional performance. According to our estimates, a dynamic region that boosts labor demand by $10 \%$ and accommodates labor force growth of $20 \%$ would experience unchanged wages, other things equal. Assessing the region only on the basis of wage growth would completely miss its success in providing new jobs, possibly to migrants who substantially increase their individual earnings.

There appear to be positive spillover effects on wages and employment from income growth in nearby areas. Our estimates suggest that for nonmetropolitan areas a 10\% increase in close neighboring regions' income is associated with a $7 \%$ increase in own wages and a $2 \%$ increase in employment. While we cannot rule out the possibility that this is due in part to a correlation with unobserved favorable factors common to the município and its environs, it suggests some support for the territorial development approach which advocates stimulating the growth of small cities in order to benefit nearby neighbors. Whether or not it is possible, in fact, to spur the growth of such cities is a different question.

Government transfers - such as pensions - appear to stimulate local wage growth. More rapid growth in receipt of transfers is associated with more rapid wage growth. Since much of the growth in transfers over the 1990s is associated with the expansion of rural pensions, this finding supports the idea that such transfers result in favorable local multiplier effects, as the pensioners increase their demand for local goods such as services and some foodstuffs. This situation has been characterized as the 'economy without production' (Maia Gomes, 2001). That epithet carries a negative connotation. A more positive view is that an increase in transfers to poor locales, with little natural or human assets, not only serves direct social needs but stimulates the local economy.

\section{Conclusions}

The paper began by mapping the heterogeneity of labor market outcomes across Brazil during the 1990s. To understand the determinants of that heterogeneity, we developed a spatial model of labor supply and demand, and applied an estimation strategy that takes into account endogeneity of the explanatory variables and spatial autocorrelation of unobserved determinants of labor force outcomes. Our results strongly emphasize the role of workforce education in determining growth prospects and the importance of local spillovers, and point to an exodus of labor from farming regions.

This paper must be viewed as an initial step in a large research agenda. Areas for further investigation include more explicit treatment of the impacts of changes in agricultural prices and technologies, including the stimulus of growth of agricultural service cities; and incorporation of better data on capital stock, and on municipal governance, agroclimate, and infrastructure. 


\section{References}

ANSELIN, L. Spatial econometrics: methods and models. Dordrecht: Kluwer Academic, 1988.

ARAUJO, C., A. de JANVRY, and E. SADOULET. 2004. Spatial patterns of nonagricultural rural employment growth in Mexico during the 90s. Department of Agricultural and Resource Economics, University of California, Berkeley. Processed.

AZZONI, C. Economic Growth and regional income inequality in Brazil. The Annals of Regional Science, v. 35, p.133-152, 2001.

AZZONI, C., MENEZES, T., MENEZES, N., NETO, R. Geografia e convergência da renda entre os estados brasileiros. In: HENRIQUES, R. (Org.). Desigualdade e pobreza no Brasil. Rio de Janeiro: IPEA, 2000, p.299-343.

AZZONI, C., SANTOS, L. (2002). Education, cost of living and regional wage inequality in Brazil in the 90's. Papers in Regional Science, v. 81, p. 157-175.

BAICKER, C. (2005). The spillover effect of state spending. Journal of Public Economics, 89(2-3), 529-544.

BAR-EL, Raphael et al. 2002. Reduzindo a Pobreza através do Desenvolvimento Econômico do Interior do Ceará. Fortaleza: Edições IPLANCE.

BARRO, R. J. (1991) Economic growth in a cross section of countries. Quarterly Journal of Economics, v.106, n.2, p.407-43, 1991.

BARRO, R.J., SALA-I-MARTIN, X. (1991) Convergence across states and regions, Brookings Papers on Economic Activity (1991) (1), pp. 107-182.

CARVALHO, A., da MATA, D., CHOMITZ, K. Estimation of Multiequation Cross-Section Models in the Presence of Spatial Autocorrelation. 2005, in prep.

CASTRO (2003). Logistic cost and Brazilian regional development. processed.

FAN, S., CHAN-KANG, S. (2004). Returns to investment in less-favored areas in developing countries: a synthesis of evidence and implications for Africa. Food Policy 29, 431-444.

FAN, S., HANZELL P., HAQUE, T. (2000). Targeting public investments by agroecological zone to achieve growth and poverty alleviation goals in rural India. Food Policy 25, 411-428.

FAN S., L. ZHANG, X. ZHANG (2002) Growth, inequality and poverty in rural China: the role of public investments. International Food Policy Research Institute, report 125.

FERREIRA, A. H. B. A distribuição interestadual e inter-regional da renda no Brasil: tendências recentes. 1995. 101f. Tese (Professor titular) - Departamento de Ciências Econômicas, Universidade Federal de Minas Gerais, Belo Horizonte, 1995. 
FERREIRA, A. H. B., DINIZ, C. C. Convergência entre as rendas per capita estaduais no Brasil. Belo Horizonte: UFMG/CEDEPLAR, 1994. 27p. (Texto para Discussão, n.79)

FERREIRA, P. C. G., ELLERY JR., R. G. Convergência entre a renda per capita dos estados brasileiros. Revista de Econometria, v.16, n.1, p.83-103, abr. 1996.

FIESS, N.M. and D. WERNER. .2004. Migration and human capital in Brazil during the 1990s. World Bank Policy Working Paper no. 3093.

GLAESER, E. L. et al. Growth in cities. Journal of Political Economy, v.100, n.6, p.11261152, Dec.1992.

GLAESER, E. L., SCHEINKMAN, J. A., SHLEIFER, A. Economic growth in a cross-section of cities. Cambridge, Mass.: NBER, 1995. 19p. (Working Papers, n.5013)

GOVERNO DO ESTADO DA BAHIA (2003) O Futuro a Gente Far: Plano Estratégico da Babia. Salvador: SEPLAN.

LALL, S., FUNDERBERG, R., YEPES, T. (2005). Location, concentration, and performance of economic activity in Brazil. World Bank Policy Research Working Paper 3268.

LUCAS, Robert. On the mechanics of economic development. Journal of Monetary Economics, v.22, n.1, p.3-42, Jul. 1988.

MAGALHÃES, A., HEWINGS, G., AZZONI, C. Spatial dependence and regional convergence in Brazil. Chicago: University of Illinois, 2000. 20p. (Working Papers REAL 00-T-11, Urbana) Disponível em: <http://www2.uiuc.edu/unit/real/d-paper/00-t-11.pdf>.

MAIA GOMES, G. 2001. Velhas secas em novos sertões: continuidade e mudanças na economica do semi-arido e dos cerrados nordestinos. Brasilia: IPEA.

PRITCHETT, L. (2004) Boom towns and ghost countries: geography, agglomeration, and population mobility. Center for Global Development, Working Paper no. 36.

RIVKIN, S., HANUSHEK, E., KAIN, J. (2005) Teachers, schools and academic achievement, Econometrica, v.73, p.417-458.

ROMER, P. M. Endogenous technological change. Journal of Political Economy, v.98, n.5 (part 2), p.71-102, Oct. 1990.

ROMER, P. M. Increasing returns and long-run growth. Journal of Political Economy, v.94, n.5, p.1002-1037, Oct. 1986.

SECRETARIA DE DESENVOLVIMENTO LOCAL E REGIONAL, n.d. (2004?). Planos de Desenvolvimento Regional. (various volumes: Baixo Jaguaribe, Maçico de Baturite, Vale deo Coreaú e Ibiapaba) Fortaleza: Governo do Estado do Ceará, Secretaria De Desenvolvimento Local e Regional. 
SILVEIRA NETO, R. M. Crescimento e spillovers: a localização importa? Evidências para os estados brasileiros. Revista Econômica do Nordeste, Fortaleza, v.32, N.ESP., p.524$545,2001$.

\section{Tables}

TABLE 1 - MCA Average

\begin{tabular}{l|c|c|c|c|c}
\hline \multirow{2}{*}{ Region } & \multicolumn{2}{|c|}{ Fertility Rate* } & \multicolumn{2}{c|}{$\begin{array}{c}\text { Percentage of immigrants } \\
\text { in population* }\end{array}$} & $\begin{array}{c}\text { Population Growth - } \\
\text { geometric annual average** }\end{array}$ \\
\cline { 2 - 6 } & 1991 & 2000 & 1991 & 2000 & $1991-2000$ \\
\hline North & 4.42 & 3.33 & 24.41 & 22.99 & 2.87 \\
Northeast & 3.89 & 2.82 & 16.99 & 16.12 & 1.29 \\
Southeast & 2.46 & 2.16 & 19.21 & 19.08 & 1.61 \\
South & 2.64 & 2.30 & 22.13 & 21.32 & 1.42 \\
Center-West & 2.82 & 2.36 & 31.95 & 29.27 & 2.33 \\
\hline
\end{tabular}

*Mean MCAs values weighted by population

** Calculated by the aggregate data

TABLE 2 - MCA Average

\begin{tabular}{l|c|c|c|c|c}
\hline \multirow{2}{*}{ Quadrant } & \multicolumn{2}{|c|}{ Fertilty Rate* } & \multicolumn{2}{c|}{$\begin{array}{c}\text { Percentage of immigrants in } \\
\text { population* }\end{array}$} & $\begin{array}{c}\text { Population Growth - geometric } \\
\text { annual average** }\end{array}$ \\
\cline { 2 - 6 } & 1991 & 2000 & 1991 & 2000 & $1991-2000$ \\
\hline E+, W+ & 2.79 & 2.31 & 25.19 & 24.32 & 2.58 \\
E-, W+ & 2.68 & 2.24 & 17.25 & 15.53 & 0.69 \\
E-, W- & 3.26 & 2.54 & 15.47 & 14.56 & 0.51 \\
E+, W- & 3.78 & 2.90 & 21.15 & 21.13 & 2.38 \\
\hline
\end{tabular}

*Mean MCAs values weighted by population

** Calculated by the aggregate data

\section{TABLE 3 - Metropolitan Areas}

\begin{tabular}{c|c|c|c|c|c|c|c|c|c}
\hline & \multicolumn{2}{|c|}{ Employment } & $\begin{array}{c}\text { Employment } \\
\text { growth }\end{array}$ & \multicolumn{2}{|c|}{ Employment Share } & \multicolumn{2}{|c|}{ Population } & $\begin{array}{c}\text { Population } \\
\text { Growth }\end{array}$ & Frequency \\
\hline Quadrant & 1991 & 2000 & & 1991 & 2000 & 1991 & 2000 & & \\
\hline E+, W+ & 14707336 & 19090991 & 4383655 & $40 \%$ & $43 \%$ & 37785537 & 47940239 & 10154702 & 332 \\
E-, W+ & 10144794 & 10924107 & 779313 & $27 \%$ & $25 \%$ & 25298240 & 27583837 & 2285597 & 154 \\
E-, W- & 6188863 & 6547091 & 358228 & $17 \%$ & $15 \%$ & 15430178 & 16591747 & 1161569 & 73 \\
E-, W- & 5978230 & 7957879 & 1979649 & $16 \%$ & $18 \%$ & 16504563 & 21302846 & 4798283 & 176 \\
\hline Total & 37021214 & 44522068 & 7500854 & $100 \%$ & $100 \%$ & 95018518 & 113420669 & 18402151 & 735 \\
\hline
\end{tabular}


TABLE 4 - Nonmetropolitan Areas

\begin{tabular}{c|c|c|c|c|c|c|c|c|c}
\hline & \multicolumn{2}{|c|}{ Employment } & $\begin{array}{c}\text { Employment } \\
\text { growth }\end{array}$ & \multicolumn{2}{|c|}{ Employment Share } & \multicolumn{2}{|c|}{ Population } & $\begin{array}{c}\text { Population } \\
\text { Growth }\end{array}$ & Frequency \\
\hline Quadrant & 1991 & 2000 & & 1991 & 2000 & 1991 & 2000 & & \\
\hline E+, W+ & 3481048 & 4551220 & 1070172 & $19 \%$ & $22 \%$ & 9300552 & 10991493 & 1690941 & 701 \\
E-, W+ & 5949685 & 5950681 & 996 & $33 \%$ & $28 \%$ & 15123906 & 15312581 & 188675 & 1172 \\
E-, W- & 4005760 & 4008645 & 2885 & $22 \%$ & $19 \%$ & 11833148 & 11888764 & 55616 & 743 \\
E-, W- & 4837597 & 6599279 & 1761682 & $26 \%$ & $31 \%$ & 15549351 & 18187663 & 2638312 & 916 \\
\hline Total & 18276081 & 21111825 & 2835744 & $100 \%$ & $100 \%$ & 51806957 & 56382501 & 4575544 & 3532 \\
\hline
\end{tabular}

TABLE 5 - All Areas

\begin{tabular}{c|c|c|c|c|c|c|c|c|c}
\hline & \multicolumn{2}{|c|}{ Employment } & $\begin{array}{c}\text { Employment } \\
\text { growth }\end{array}$ & \multicolumn{2}{c|}{$\begin{array}{c}\text { Share of } \\
\text { employment }\end{array}$} & \multicolumn{2}{|c|}{ Population } & $\begin{array}{c}\text { Population } \\
\text { Growth }\end{array}$ & Frequency \\
\hline Quadrant & 1991 & 2000 & & 1991 & 2000 & 1991 & 2000 & & \\
\cline { 2 - 10 } E+, W+ & 18188385 & 23642211 & 5453826 & $32 \%$ & $35 \%$ & 47086089 & 58931732 & 11845643 & 1033 \\
E-, W+ & 16094479 & 16874788 & 780309 & $28 \%$ & $25 \%$ & 40422146 & 42896418 & 2474272 & 1326 \\
E-, W- & 10194623 & 10555736 & 361113 & $19 \%$ & $17 \%$ & 27263326 & 28480511 & 1217185 & 816 \\
E+, W- & 10815827 & 14557158 & 3741331 & $22 \%$ & $23 \%$ & 32053914 & 39490509 & 7436595 & 1092 \\
\cline { 2 - 10 } Total & 55295305 & 65631893 & 10336588 & $100 \%$ & $100 \%$ & 146825475 & 169801170 & 22975695 & 4267 \\
\hline
\end{tabular}




\section{Table 6. Variables and Sources}

A. Variables used in the Wage Equation and their sources:

\begin{tabular}{|c|c|c|c|}
\hline Variable & Source & Instrument(s) & Source \\
\hline Teacher qualification in 1991 & IBGE - Census & Exogenous & \\
\hline Years of schooling in 1991 & IBGE - Census & Exogenous & \\
\hline Total precipitation & DECRG - IE & Exogenous & \\
\hline Government with Accountability & IBGE - MUNIC & Exogenous & \\
\hline \multirow{3}{*}{ Delta employment } & \multirow{3}{*}{ IBGE - Census } & Employment rate in 1991 & IBGE - Census \\
\hline & & Soil quality & DECRG - IE \\
\hline & & $\begin{array}{l}\text { First and third principal components of } \\
\text { monthly rainfall }\end{array}$ & DECRG - IE \\
\hline Transport cost to São Paulo & NEMESIS & Transport cost to São Paulo in 1968 & NEMESIS \\
\hline $\begin{array}{c}\text { Transport cost to nearest State } \\
\text { Capital }\end{array}$ & NEMESIS & $\begin{array}{l}\text { Transport cost to nearest State Capital in } \\
1968\end{array}$ & NEMESIS \\
\hline \multirow{6}{*}{ Delta government transference } & \multirow{6}{*}{ IBGE - Census } & Dependency ratio in 1991 & IBGE - Census \\
\hline & & Illiteracy rate in 1991 & IBGE - Census \\
\hline & & Repetition rate in 1991 & IBGE - Census \\
\hline & & Proportion of elderly persons in 1991 & IBGE - Census \\
\hline & & Population in 1991 & IBGE - Census \\
\hline & & Proportion 5-15 over $15-55$ yrs old in 1991 & IBGE - Census \\
\hline \multirow{3}{*}{ Delta Market Potential } & \multirow{3}{*}{ DECRG - IE } & Delta education market potential & DECRG - IE \\
\hline & & Urbanization rate in 1991 & IBGE - Census \\
\hline & & Population density in 1991 & IBGE - Census \\
\hline
\end{tabular}


B. Variables used in the Labor Equation and their sources:

\begin{tabular}{|cccc|}
\hline Variable & Source & Instrument(s) & Source \\
\hline Wage in 1991 & IBGE - Census & Exogenous & \\
\hline Proportion 5-15 over15-55 yrs old & IBGE - Census & Exogenous \\
\hline Proportion native in 1991 & IBGE - Census & Exogenous \\
\hline Delta market potential & DECRG - IE & Exogenous \\
\hline Teacher qualification in 1991 & IBGE - Census & Exogenous \\
\hline Homicides per capita in 1991 & DATASUS & Exogenous \\
\hline Proportion farmers in 1991 & IBGE - Census & Exogenous \\
\hline Bank Dummy & Central Bank & Exogenous \\
\hline Population in 1991 & IBGE - Census & Exogenous & \\
\hline Mean Temperature & DECRG - IE & Exogenous & \\
\hline Total Rainfall & DECRG - IE & Exogenous & \\
\hline Rainfall - 10 Principal Component & DECRG - IE & Exogenous & \\
\hline Rainfall - 3울incipal Component & DECRG - IE & Exogenous & \\
\hline Employment rate in 1991 & IBGE - Census & Illiteracy rate in 1991 & IBGE - Census \\
& & Fertility rate in 1991 & IBGE - Census \\
\hline
\end{tabular}


Table 7A. Summary Statistics, all Brazil

\begin{tabular}{|c|c|c|c|c|c|}
\hline Variable & Obs & Mean & Std.Dev. & Min & Max \\
\hline Delta In Wage (2000/1991) & 4267 & -0.0101 & 0.2935 & -1.5242 & 0.8495 \\
\hline In Teacher qualification in 1991 & 4267 & 1.3938 & 2.1088 & -4.6052 & 4.2370 \\
\hline Years of Schooling in 1991 & 4267 & 3.9181 & 1.4556 & 0.4425 & 9.6572 \\
\hline Total rainfall & 4266 & 1337.3190 & 425.4345 & 368.6636 & 3361.7090 \\
\hline Government Accountability & 4267 & 0.9121 & 0.2832 & 0.0000 & 1.0000 \\
\hline Delta In Employment (2000/1991) & 4267 & 0.1422 & 0.2224 & -0.6961 & 1.8755 \\
\hline InTransport Cost to São Paulo in 1995 & 4266 & 7.0420 & 0.8469 & 2.3026 & 9.2603 \\
\hline $\begin{array}{c}\text { In Transport Cost to State Capital in } \\
1995\end{array}$ & 4256 & 5.8180 & 0.7780 & 1.3863 & 8.6910 \\
\hline Delta In Transferences (2000/1991) & 4267 & 0.8083 & 0.3221 & -1.1823 & 2.4240 \\
\hline Delta In Market Potential (2000/1991) & 4,258 & 0.4093 & 0.1375 & -0.4691 & 2.0949 \\
\hline In Population in 1991 & 4,267 & 9.5287 & 1.0888 & 6.6214 & 16.0821 \\
\hline Dependency Ratio in 1991 & 4267 & 0.4775 & 0.0466 & 0.3738 & 0.6205 \\
\hline In Transport Cost to São Paulo in 1968 & 4266 & 7.6264 & 0.7874 & 3.2189 & 9.6385 \\
\hline $\begin{array}{c}\text { In Transport Cost to State Capital in } \\
1968\end{array}$ & 4256 & 6.2548 & 0.7959 & 1.3863 & 8.6910 \\
\hline In Proportion of Elderly in 1991 & 4267 & -2.2502 & 0.2621 & -3.9145 & -1.5332 \\
\hline Illiteracy Rate in 1991 & 4267 & 35.5004 & 17.8266 & 2.4800 & 87.0500 \\
\hline Urbanization Rate in 1991 & 4267 & 53.6356 & 23.1683 & 2.1562 & 100.0000 \\
\hline Population Density in 1991 & 4267 & 93.6426 & 510.3321 & 0.0896 & 12199.7700 \\
\hline In 5 to 15 over 15 to 55 years old Ratio & 4267 & -0.7491 & 0.2303 & -1.6218 & -0.0354 \\
\hline Repetition Rate in 1991 & 4267 & 4.2935 & 0.2071 & 2.3542 & 4.5756 \\
\hline In Employment Rate in 1991 & 4267 & -0.3760 & 0.1411 & -1.2429 & 0.1601 \\
\hline $\begin{array}{l}\text { Delta In Education Market Potential } \\
\qquad(2000 / 1991)\end{array}$ & 4251 & 0.9737 & 0.1736 & 0.0535 & 2.7704 \\
\hline Percentage of Good Soils & 4266 & 0.7904 & 0.3071 & 0.0000 & 1.0002 \\
\hline Rainfall - First Principal Component & 4266 & 0.0000 & 2.2685 & -4.2315 & 6.9861 \\
\hline Rainfall - Third Principal Component & 4,266 & 0.0000 & 1.5749 & -2.6324 & 9.2440 \\
\hline In Wage in 1991 & 4267 & 8.0265 & 0.4963 & 6.6139 & 9.8121 \\
\hline Proportion of Natives in 1991 & 4267 & 0.6565 & 0.1790 & 0.0855 & 1.0134 \\
\hline Homicides per Capita in 1991 & 4265 & 0.0016 & 0.0011 & 0.0000 & 0.0090 \\
\hline $\begin{array}{l}\text { Employment in Farming Activities in } \\
1991\end{array}$ & 4,267 & 0.1777 & 0.0854 & 0.0000 & 0.5437 \\
\hline \multirow[t]{2}{*}{ Bank Dummy (1991) } & 4,267 & 0.7492 & 0.4335 & 0.0000 & 1.0000 \\
\hline & 4267 & 9.5287 & 1.0888 & 6.6214 & 16.0821 \\
\hline Average Temperature & 4266 & 22.3050 & 2.8451 & 13.8325 & 27.8109 \\
\hline Fertility Rate in 1991 & 4,267 & 3.6449 & 1.1885 & 1.7600 & 8.6800 \\
\hline
\end{tabular}


Table 7B, Summary statistics, Non-metropolitan Brazil

\begin{tabular}{|c|c|c|c|c|c|}
\hline Variable & Obs & Mean & Std.Dev. & Min & Max \\
\hline Delta In Wage (2000/1991) & 3532 & -0.0233 & 0.3097 & -1.5242 & 0.8495 \\
\hline In Teacher qualification in 1991 & 3532 & 1.1990 & 2.1519 & -4.6052 & 4.2370 \\
\hline Years of Schooling in 1991 & 3532 & 3.6414 & 1.3197 & 0.4425 & 7.1707 \\
\hline Total rainfall & 3,531 & $1,312.3340$ & 436.0881 & 368.6636 & $3,361.7090$ \\
\hline Government Accountability & 3,532 & 0.9023 & 0.2969 & 0.0000 & 1.0000 \\
\hline Delta In Employment (2000/1991) & 3532 & 0.1231 & 0.2173 & -0.6577 & 1.3689 \\
\hline InTransport Cost to São Paulo in 1995 & 3531 & 7.1172 & 0.7733 & 4.1589 & 9.2603 \\
\hline $\begin{array}{c}\text { In Transport Cost to State Capital in } \\
1995\end{array}$ & 3531 & 5.9358 & 0.6736 & 2.1972 & 8.6910 \\
\hline Delta In Transferences (2000/1991) & 3532 & 0.8316 & 0.3262 & -1.1823 & 2.4240 \\
\hline Delta In Market Potential (2000/1991) & 3523 & 0.4053 & 0.1330 & -0.4691 & 2.0949 \\
\hline In Population in 1991 & 3,532 & 9.2629 & 0.8171 & 6.6214 & 12.9814 \\
\hline Dependency Ratio in 1991 & 3532 & 0.4840 & 0.0460 & 0.3738 & 0.6205 \\
\hline In Transport Cost to São Paulo in 1968 & 3531 & 7.6962 & 0.7123 & 4.3694 & 9.6385 \\
\hline $\begin{array}{c}\text { In Transport Cost to State Capital in } \\
1968\end{array}$ & 3531 & 6.3629 & 0.7037 & 3.1135 & 8.6910 \\
\hline In Proportion of Elderly in 1991 & 3532 & -2.2260 & 0.2566 & -3.9145 & -1.5332 \\
\hline Illiteracy Rate in 1991 & 3532 & 38.0138 & 17.5883 & 2.4800 & 87.0500 \\
\hline Urbanization Rate in 1991 & 3532 & 48.7978 & 20.6294 & 2.7639 & 100.0000 \\
\hline Population Density in 1991 & 3532 & 31.1089 & 33.0202 & 0.0896 & 522.2028 \\
\hline In 5 to 15 over 15 to 55 years old Ratio & 3,532 & -0.7264 & 0.2329 & -1.6218 & -0.0354 \\
\hline Repetition Rate in 1991 & 3,532 & 4.2707 & 0.2125 & 2.3542 & 4.5756 \\
\hline In Employment Rate in 1991 & 3532 & -0.3722 & 0.1462 & -1.2429 & 0.1601 \\
\hline $\begin{array}{l}\text { Delta In Education Market Potential } \\
(2000 / 1991)\end{array}$ & 3516 & 0.9745 & 0.1732 & 0.0535 & 2.7704 \\
\hline Percentage of Good Soils & 3531 & 0.7816 & 0.3179 & 0.0000 & 1.0002 \\
\hline Rainfall - First Principal Component & 3531 & 0.0033 & 2.2334 & -4.2315 & 6.8953 \\
\hline Rainfall - Third Principal Component & 3531 & 0.0262 & 1.6087 & -2.4997 & 9.2440 \\
\hline In Wage in 1991 & 3532 & 7.9349 & 0.4619 & 6.6139 & 9.3168 \\
\hline Proportion of Natives in 1991 & 3532 & 0.6778 & 0.1760 & 0.0855 & 1.0134 \\
\hline Homicides per Capita in 1991 & 3530 & 0.0015 & 0.0010 & 0.0000 & 0.0090 \\
\hline $\begin{array}{l}\text { Employment in Farming Activities in } \\
1991\end{array}$ & 3532 & 0.1975 & 0.0743 & 0.0000 & 0.5437 \\
\hline \multirow[t]{2}{*}{ Bank Dummy (1991) } & 3532 & 0.7087 & 0.4544 & 0.0000 & 1.0000 \\
\hline & 3532 & 9.2629 & 0.8171 & 6.6214 & 12.9814 \\
\hline Average Temperature & 3531 & 22.4151 & 2.8196 & 13.8325 & 27.7363 \\
\hline Fertility Rate in 1991 & 3532 & 3.7759 & 1.2169 & 2.0100 & 8.6800 \\
\hline
\end{tabular}


Table 7C. Summary statistics, Non-metropolitan Brazil without North Region

\begin{tabular}{|c|c|c|c|c|c|}
\hline Variable & Obs & Mean & Std.Dev. & Min & Max \\
\hline Delta In Wage (2000/1991) & 3300 & 0.0000 & 0.2901 & -1.3942 & 0.8495 \\
\hline In Teacher qualification in 1991 & 3300 & 1.3156 & 2.1187 & -4.6052 & 4.2370 \\
\hline Years of Schooling in 1991 & 3300 & 3.6858 & 1.3320 & 0.4746 & 7.1707 \\
\hline Total rainfall & 3299 & 1251.7990 & 367.9959 & 368.6636 & 2532.2020 \\
\hline Government Accountability & 3300 & 0.9124 & 0.2827 & 0.0000 & 1.0000 \\
\hline Delta In Employment (2000/1991) & 3300 & 0.1103 & 0.2035 & -0.6577 & 1.2464 \\
\hline InTransport Cost to São Paulo in 1995 & 3299 & 7.0422 & 0.7355 & 4.1589 & 8.3051 \\
\hline $\begin{array}{c}\text { In Transport Cost to State Capital in } \\
1995\end{array}$ & 3299 & 5.8691 & 0.6163 & 2.1972 & 7.7619 \\
\hline Delta In Transferences (2000/1991) & 3300 & 0.8448 & 0.3073 & -0.2986 & 2.3336 \\
\hline Delta In Market Potential (2000/1991) & 3299 & 0.4101 & 0.1179 & -0.2664 & 1.5442 \\
\hline In Population in 1991 & 3300 & 9.2337 & 0.8054 & 6.6214 & 11.9770 \\
\hline Dependency Ratio in 1991 & 3300 & 0.4807 & 0.0447 & 0.3738 & 0.6205 \\
\hline In Transport Cost to São Paulo in 1968 & 3299 & 7.6219 & 0.6676 & 4.3694 & 8.7367 \\
\hline $\begin{array}{c}\text { In Transport Cost to State Capital in } \\
1968\end{array}$ & 3299 & 6.2990 & 0.6601 & 3.1135 & 7.9077 \\
\hline In Proportion of Elderly in 1991 & 3300 & -2.1936 & 0.2204 & -3.6893 & -1.5332 \\
\hline Illiteracy Rate in 1991 & 3300 & 37.7150 & 17.8150 & 2.4800 & 81.4600 \\
\hline Urbanization Rate in 1991 & 3300 & 49.2604 & 20.7435 & 2.7639 & 100.0000 \\
\hline Population Density in 1991 & 3300 & 32.7412 & 33.3495 & 0.2065 & 522.2028 \\
\hline In 5 to 15 over 15 to 55 years old Ratio & 3300 & -0.7464 & 0.2243 & -1.6218 & -0.1870 \\
\hline Repetition Rate in 1991 & 3300 & 4.2817 & 0.1976 & 2.6575 & 4.5756 \\
\hline In Employment Rate in 1991 & 3300 & -0.3625 & 0.1406 & -1.2429 & 0.1601 \\
\hline $\begin{array}{l}\text { Delta In Education Market Potential } \\
\qquad(2000 / 1991)\end{array}$ & 3297 & 0.9707 & 0.1575 & 0.1650 & 1.6027 \\
\hline Percentage of Good Soils & 3299 & 0.7881 & 0.3192 & 0.0000 & 1.0002 \\
\hline Rainfall - First Principal Component & 3299 & -0.0130 & 2.1967 & -4.2315 & 6.8953 \\
\hline Rainfall - Third Principal Component & 3299 & -0.1705 & 1.3696 & -2.4997 & 5.4633 \\
\hline In Wage in 1991 & 3300 & 7.9233 & 0.4684 & 6.6139 & 9.3168 \\
\hline Proportion of Natives in 1991 & 3300 & 0.6765 & 0.1694 & 0.0855 & 1.0134 \\
\hline Homicides per Capita in 1991 & 3299 & 0.0015 & 0.0010 & 0.0000 & 0.0090 \\
\hline $\begin{array}{l}\text { Employment in Farming Activities in } \\
1991\end{array}$ & 3300 & 0.1995 & 0.0752 & 0.0000 & 0.5437 \\
\hline Bank Dummy (1991) & 3300 & 0.7197 & 0.4492 & 0.0000 & 1.0000 \\
\hline Average Temperature & 3299 & 22.1518 & 2.7223 & 13.8325 & 27.7363 \\
\hline Fertility Rate in 1991 & 3300 & 3.6513 & 1.1051 & 2.0100 & 7.9600 \\
\hline
\end{tabular}


Table 8: Regression results, Brazilwide

\begin{tabular}{|c|c|c|c|c|}
\hline $\begin{array}{c}\text { Dependent Variable: } \\
\text { Delta In Wage }\end{array}$ & 2SLS Est. & 2SLS SE & $\begin{array}{c}\text { Spatial GMM } \\
\text { Est. } \\
\text { (Cutoff }=0.5)\end{array}$ & $\begin{array}{c}\text { Spatial GMM } \\
\text { SE } \\
\text { (Cutoff }=0.5)\end{array}$ \\
\hline Intercept & -.23969856 & .06883838 & -.56879473 & .30864844 \\
\hline In Teacher qualification in 1991 & .00548926 & .00230455 & .00416922 & .0057475 \\
\hline Years of Schooling in 1991 & .06204049 & .00435942 & .05989964 & .01154468 \\
\hline Total Rainfall & .00005344 & $9.645 e-06$ & .00006334 & .00002661 \\
\hline Government Accountability & .02233476 & .01293292 & .01689856 & .03458774 \\
\hline Delta In Employment & -.49393135 & .05272667 & -.60942137 & .21566178 \\
\hline In Transport Cost SP in 1995 & -.03205953 & .00590571 & -.02147947 & .02295913 \\
\hline In Transport Cost Capital in 1995 & -.04812287 & .00601824 & -.01909574 & .02022743 \\
\hline Delta In Transferences & .29663134 & .03118072 & .20129193 & .11094594 \\
\hline Delta In Market Potential & .54819572 & .09031346 & .98877352 & .29459548 \\
\hline crit. fn. test of overid. restrictions & --- & --- & 24.106339 & 24.106339 \\
\hline
\end{tabular}

\begin{tabular}{|c|c|c|c|c|}
\hline $\begin{array}{c}\text { Dependent Variable: } \\
\text { Delta In Wage }\end{array}$ & $\begin{array}{c}\text { Spatial GMM } \\
\text { Est. } \\
(\text { Cutoff }=1)\end{array}$ & $\begin{array}{c}\text { Spatial GMM } \\
\text { SE } \\
(\text { Cutoff }=1)\end{array}$ & $\begin{array}{c}\text { Spatial GMM } \\
\text { Est. } \\
(\text { Cutoff }=2)\end{array}$ & $\begin{array}{c}\text { Spatial GMM } \\
\text { SE } \\
\text { (Cutoff }=2)\end{array}$ \\
\hline Intercept & -.71932918 & .39269048 & -.89149666 & .46470872 \\
\hline In Teacher qualification in 1991 & .00313908 & .00588544 & .00077822 & .00636871 \\
\hline Years of Schooling in 1991 & .06201083 & .01286978 & .06663528 & .01474433 \\
\hline Total Rainfall & .0000674 & .00002795 & .00007651 & .00002947 \\
\hline Government Accountability & .02179158 & .03504303 & .03300684 & .035756 \\
\hline Delta In Employment & -.74141878 & .24696933 & -.89418358 & .27639595 \\
\hline In Transport Cost SP in 1995 & -.01160188 & .02949758 & .00306388 & .03553532 \\
\hline In Transport Cost Capital in 1995 & -.00840394 & .02391369 & .00218674 & .02606355 \\
\hline Delta In Transferences & .13809767 & .12475475 & .05152986 & .13939323 \\
\hline Delta In Market Potential & 1.1562178 & .34490082 & 1.3035762 & .36538869 \\
\hline crit. fn. test of overid. restrictions & 19.804367 & 19.804367 & 14.762519 & 14.762519 \\
\hline
\end{tabular}




\begin{tabular}{|c|c|c|c|c|}
\hline $\begin{array}{l}\text { Dependent Variable: } \\
\text { Delta In Employment }\end{array}$ & 2SLS Est. & 2SLS SE & $\begin{array}{l}\text { Spatial GMM } \\
\text { Est. } \\
(\text { Cutoff }=0.5)\end{array}$ & $\begin{array}{c}\text { Spatial GMM } \\
\text { SE } \\
\text { (Cutoff }=0.5 \text { ) }\end{array}$ \\
\hline Intercept & -.61966401 & .1396479 & -.59779578 & .19288857 \\
\hline In Wage in 1991 & .18148355 & .01471158 & .1805902 & .02061008 \\
\hline In 5 to 15 over 15 to 55 yrs Ratio & .32737947 & .03751615 & .3284415 & .05359506 \\
\hline Proportion of Natives in 1991 & .26274058 & .04047279 & .28160825 & .06166641 \\
\hline Delta In Market Potential & .23244707 & .02541535 & .22884513 & .04132408 \\
\hline In Teacher qualification in 1991 & -.01008945 & .0023123 & -.01034963 & .00348222 \\
\hline Homicides in 1991 & -23.377317 & 4.2814245 & -26.064766 & 11.646685 \\
\hline Employment in Farming in 1991 & -1.0925149 & .16331391 & -1.160606 & .25061706 \\
\hline Bank Dummy & -.00883696 & .00937983 & -.00637937 & .01263533 \\
\hline In Population in 1991 & -.0271189 & .00513829 & -.02845369 & .00796092 \\
\hline Mean Temperature & -.00216998 & .00263983 & -.00152014 & .00396835 \\
\hline Total Rainfall & .00002401 & .00001217 & .00002763 & .00001916 \\
\hline Rainfall - $1^{\circ}$ Princ. Component & .00693925 & .00183254 & .00660851 & .00291956 \\
\hline Rainfall - 3ํP Princ. Component & .01082346 & .00425524 & .0101329 & .00634718 \\
\hline Employment rate in 1991 & .50765127 & .14583623 & .55593884 & .22256766 \\
\hline crit. fn. test of overid. restrictions & --- & $-\overline{--}$ & 4.3194265 & 4.3194265 \\
\hline $\begin{array}{l}\text { Dependent Variable: } \\
\text { Delta In Employment }\end{array}$ & $\begin{array}{c}\text { Spatial GMM } \\
\text { Est. } \\
(\text { Cutoff }=1)\end{array}$ & $\begin{array}{c}\text { Spatial GMM } \\
\text { SE } \\
\text { (Cutoff }=1)\end{array}$ & $\begin{array}{l}\text { Spatial GMM } \\
\text { Est. } \\
(\text { Cutoff }=2)\end{array}$ & $\begin{array}{c}\text { Spatial GMM } \\
\text { SE } \\
(\text { Cutoff }=2)\end{array}$ \\
\hline Intercept & -.58264148 & .21309273 & -.55973566 & .23194173 \\
\hline In Wage in 1991 & .17833635 & .02288821 & .17472738 & .02582378 \\
\hline In 5 to 15 over 15 to 55 yrs Ratio & .32701012 & .05974778 & .32103962 & .06498975 \\
\hline Proportion of Natives in 1991 & .28581622 & .07064752 & .2838648 & .08167097 \\
\hline Delta In Market Potential & .22956501 & .04807927 & .22942847 & .05732953 \\
\hline In Teacher qualification in 1991 & -.01069225 & .00410323 & -.01055971 & .00482079 \\
\hline Homicides in 1991 & -29.090509 & 16.986828 & -34.329254 & 26.672443 \\
\hline Employment in Farming in 1991 & -1.1970719 & .28437662 & -1.2222365 & .31455466 \\
\hline Bank Dummy & -.00550414 & .01287836 & -.00412273 & .01383933 \\
\hline In Population in 1991 & -.028508 & .00898918 & -.02745768 & .01065978 \\
\hline Mean Temperature & -.00111862 & .00469047 & -.00119964 & .00556795 \\
\hline Total Rainfall & .00003371 & .00002314 & .00003857 & .00002848 \\
\hline Rainfall - $1^{\circ}$ Princ. Component & .00608015 & .00340453 & .0056972 & .00382822 \\
\hline Rainfall - $3^{\circ}$ Princ. Component & .00928193 & .00771074 & .00883827 & .00899555 \\
\hline Employment rate in 1991 & .5768252 & .24739395 & .58084285 & .26483339 \\
\hline crit. fn. test of overid. restrictions & 3.4865079 & 3.4865079 & 2.7619863 & 2.7619863 \\
\hline
\end{tabular}


Table 9: Regression results, Non-metropolitan Brazil

\begin{tabular}{|c|c|c|c|c|}
\hline $\begin{array}{c}\text { Dependent Variable: } \\
\text { Delta In Wage }\end{array}$ & 2SLS Est. & 2SLS SE & $\begin{array}{c}\text { Spatial GMM } \\
\text { Est. } \\
(\text { Cutoff }=0.5)\end{array}$ & $\begin{array}{c}\text { Spatial GMM } \\
\text { SE } \\
\text { (Cutoff }=0.5)\end{array}$ \\
\hline Intercept & .09597151 & .10607452 & -.07212585 & .15562966 \\
\hline In Teacher qualification in 1991 & .00297498 & .00255803 & -.00046191 & .00367207 \\
\hline Years of Schooling in 1991 & .06753124 & .00544935 & .06342638 & .00746079 \\
\hline Total Rainfall & .00005995 & .00001096 & .00007959 & .00001616 \\
\hline Government Accountability & .01715587 & .01423606 & .00466584 & .02099178 \\
\hline Delta In Employment & -.58726752 & .07915421 & -.72860634 & .13080938 \\
\hline In Transport Cost SP in 1995 & -.05128457 & .00834921 & -.04954901 & .01126003 \\
\hline In Transport Cost Capital in 1995 & -.06169838 & .00863113 & -.04358863 & .0138009 \\
\hline Delta In Transferences & .24978392 & .04062804 & .16556984 & .06593844 \\
\hline Delta In Market Potential & .33007705 & .12288672 & .67970574 & .17956081 \\
\hline crit. fn. test of overid. restrictions & ---- & ---- & 51.198551 & 51.198551 \\
\hline
\end{tabular}

\begin{tabular}{|c|c|c|c|c|}
\hline $\begin{array}{c}\text { Dependent Variable: } \\
\text { Delta In Wage }\end{array}$ & $\begin{array}{c}\text { Spatial GMM } \\
\text { Est. } \\
(\text { Cutoff }=1)\end{array}$ & $\begin{array}{c}\text { Spatial GMM } \\
\text { SE } \\
(\text { Cutoff }=1\end{array}$ & $\begin{array}{c}\text { Spatial GMM } \\
\text { Est. } \\
(\text { Cutoff }=2)\end{array}$ & $\begin{array}{c}\text { Spatial GMM } \\
\text { SE } \\
(\text { Cutoff }=2)\end{array}$ \\
\hline Intercept & -.04565513 & .17729723 & -.0494362 & .21368676 \\
\hline In Teacher qualification in 1991 & -.00177951 & .00383909 & -.00199813 & .00412284 \\
\hline Years of Schooling in 1991 & .06576312 & .00830697 & .06912613 & .00973923 \\
\hline Total Rainfall & .00008265 & .0000173 & .00007853 & .0000177 \\
\hline Government Accountability & .00246969 & .02073262 & .00032706 & .01966279 \\
\hline Delta In Employment & -.73485869 & .14010873 & -.74297255 & .15258759 \\
\hline In Transport Cost SP in 1995 & -.05022805 & .01231244 & -.04537549 & .01413209 \\
\hline In Transport Cost Capital in 1995 & -.04676843 & .01599272 & -.04803535 & .01860846 \\
\hline Delta In Transferences & .16973922 & .07140593 & .16184129 & .08098298 \\
\hline Delta In Market Potential & .64660937 & .19555643 & .60036469 & .22895648 \\
\hline crit. fn. test of overid. restrictions & 35.984318 & 35.984318 & 22.100483 & 22.100483 \\
\hline
\end{tabular}




\begin{tabular}{|c|c|c|c|c|}
\hline $\begin{array}{l}\text { Dependent Variable: } \\
\text { Delta In Employment }\end{array}$ & 2SLS Est. & 2SLS SE & $\begin{array}{l}\text { Spatial GMM } \\
\text { Est. } \\
\text { (Cutoff }=0.5 \text { ) }\end{array}$ & $\begin{array}{c}\text { Spatial GMM } \\
\text { SE } \\
(\text { Cutoff }=0.5)\end{array}$ \\
\hline Intercept & -1.0038159 & .14846142 & -.97731119 & .21782738 \\
\hline In Wage in 1991 & .19207975 & .01553089 & .190244 & .02302395 \\
\hline In 5 to 15 over 15 to 55 yrs Ratio & .25067678 & .03711903 & .24860755 & .0545722 \\
\hline Proportion of Natives in 1991 & .292077 & .04174566 & .31104589 & .06760336 \\
\hline Delta In Market Potential & 2035026 & .02778313 & .19855203 & .04571589 \\
\hline In Teacher Qualification in 1991 & -.00699189 & .00239773 & -.00710868 & .00376014 \\
\hline Homicides in 1991 & -9.7408304 & 4.5089288 & -13.952994 & 12.869347 \\
\hline Employment in Farming in 1991 & -.55168569 & .17153628 & -.62525272 & .27117524 \\
\hline Bank Dummy & -.0029771 & .00978021 & .00085738 & .01357927 \\
\hline In Population in 1991 & -.02653262 & .00623792 & -.02801059 & .009894 \\
\hline Mean Temperature & -.00246354 & .00267179 & -.00177658 & .00416755 \\
\hline Total Rainfall & $3.313 e-06$ & .00001244 & $7.357 \mathrm{e}-06$ & .00002025 \\
\hline Rainfall - 1ํP. Princ. Component & .00715906 & .00194123 & .00712434 & .0032946 \\
\hline Rainfall - 3ํP Princ. Component & .01638063 & .0044276 & .01515498 & .00688489 \\
\hline Employment rate in 1991 & .17582282 & .14548762 & .21597567 & .23001887 \\
\hline crit. fn. test of overid. restrictions & --- & $\overline{----}$ & 6.5507803 & 6.5507803 \\
\hline $\begin{array}{l}\text { Dependent Variable: } \\
\text { Delta In Employment }\end{array}$ & $\begin{array}{l}\text { Spatial GMM } \\
\text { Est. } \\
(\text { Cutoff }=1)\end{array}$ & $\begin{array}{c}\text { Spatial GMM } \\
\text { SE } \\
\text { (Cutoff }=1\end{array}$ & $\begin{array}{l}\text { Spatial GMM } \\
\text { Est. } \\
\text { (Cutoff }=2)\end{array}$ & $\begin{array}{c}\text { Spatial GMM } \\
\text { SE } \\
\text { (Cutoff }=2)\end{array}$ \\
\hline Intercept & -.94565964 & .24317868 & -.8953951 & .27096564 \\
\hline In Wage in 1991 & .1860382 & .02520692 & .17956887 & .02802359 \\
\hline In 5 to 15 over 15 to 55 yrs Ratio & .2456395 & .06085758 & .2379445 & .06769622 \\
\hline Proportion of Natives in 1991 & .31289083 & .07724686 & .30829117 & .08909906 \\
\hline Delta In Market Potential & .19815785 & .05295998 & .19621347 & .06306989 \\
\hline In Teacher Qualification in 1991 & -.00740787 & .00443293 & -.00709898 & .00504883 \\
\hline Homicides in 1991 & -18.404268 & 18.498964 & -26.86664 & 28.508017 \\
\hline Employment in Farming in 1991 & -.6742841 & .31386852 & -.72451919 & .35913906 \\
\hline Bank Dummy & .00197269 & .0137091 & .00300001 & .01441328 \\
\hline In Population in 1991 & -.02758414 & .01119957 & -.02459399 & .01372423 \\
\hline Mean Temperature & -.00145903 & .00495593 & -.00197288 & .00596594 \\
\hline Total Rainfall & .00001497 & .00002414 & .00002119 & .00002897 \\
\hline Rainfall - $1^{\circ}$ Princ. Component & .00662112 & .00376597 & .00617786 & .00420715 \\
\hline Rainfall - 3ํP Princ. Component & .01389925 & .00844409 & .01335848 & .009971 \\
\hline Employment rate in 1991 & .23755644 & .25803682 & .25136152 & .28428775 \\
\hline crit. fn. test of overid. restrictions & 5.2505856 & 5.2505856 & 4.0939112 & 4.0939112 \\
\hline
\end{tabular}


Table 10: Non-Metropolitan Brazil excluding North Region

\begin{tabular}{|c|c|c|c|c|}
\hline $\begin{array}{c}\text { Dependent Variable: } \\
\text { Delta In Wage }\end{array}$ & 2SLS Est. & 2SLS SE & $\begin{array}{c}\text { Spatial GMM } \\
\text { Est. } \\
\text { (Cutoff }=0.5)\end{array}$ & $\begin{array}{c}\text { Spatial GMM } \\
\text { SE } \\
\text { (Cutoff }=0.5)\end{array}$ \\
\hline Intercept & -.15950009 & .10277873 & -.12074952 & .17974661 \\
\hline In Teacher Qualification in 1991 & .0052535 & .00254925 & .00236128 & .00410509 \\
\hline Years of Schooling in 1991 & .06246437 & .00536942 & .06088094 & .0082013 \\
\hline Total Rainfall & .00007979 & .00001297 & .00009786 & .00002296 \\
\hline Government Accountability & -.00584819 & .01443974 & -.00617702 & .02409457 \\
\hline Delta In Employment & -.53408098 & .07787127 & -.63237196 & .14710456 \\
\hline In Transport Cost SP in 1995 & -.0404624 & .00821161 & -.04469861 & .0127028 \\
\hline In Transport Cost Capital in 1995 & -.04374225 & .00881383 & -.0422301 & .01622356 \\
\hline Delta In Transferences & .22328359 & .04042839 & .18064082 & .07351591 \\
\hline Delta In Market Potential & .58404297 & .11290579 & .62033021 & .18144919 \\
\hline crit. fn. test of overid. restrictions & ---- & --- & 44.336521 & 44.336521 \\
\hline
\end{tabular}

\begin{tabular}{|c|c|c|c|c|}
\hline $\begin{array}{c}\text { Dependent Variable: } \\
\text { Delta In Wage }\end{array}$ & $\begin{array}{c}\text { Spatial GMM } \\
\text { Est. } \\
(\text { Cutoff }=1)\end{array}$ & $\begin{array}{c}\text { Spatial GMM } \\
\text { SE } \\
(\text { Cutoff }=1\end{array}$ & $\begin{array}{c}\text { Spatial GMM } \\
\text { Est. } \\
(\text { Cutoff }=2)\end{array}$ & $\begin{array}{c}\text { Spatial GMM } \\
\text { SE } \\
\text { (Cutoff }=2)\end{array}$ \\
\hline Intercept & -.04462965 & .19892652 & .00716942 & .22615147 \\
\hline In Teacher Qualification in 1991 & .00093057 & .00426831 & .00001553 & .00453575 \\
\hline Years of Schooling in 1991 & .06330124 & .00894142 & .06656591 & .01025243 \\
\hline Total Rainfall & .00010275 & .00002402 & .00010328 & .00002395 \\
\hline Government Accountability & -.01646986 & .02421216 & -.02936971 & .02324613 \\
\hline Delta In Employment & -.68066132 & .16307582 & -.76383001 & .18872485 \\
\hline In Transport Cost SP in 1995 & -.04688983 & .01363969 & -.042707 & .01531044 \\
\hline In Transport Cost Capital in 1995 & -.04913757 & .01864702 & -.05431722 & .02134752 \\
\hline Delta In Transferences & .17948617 & .0803842 & .15744109 & .09175749 \\
\hline Delta In Market Potential & .58104956 & .19482417 & .52911681 & .22650729 \\
\hline crit. fn. test of overid. restrictions & 33.939201 & 33.939201 & 21.138334 & 21.138334 \\
\hline
\end{tabular}




\begin{tabular}{|c|c|c|c|c|}
\hline $\begin{array}{l}\text { Dependent Variable: } \\
\text { Delta In Employment }\end{array}$ & 2SLS.Est. & 2SLS.SE & $\begin{array}{l}\text { Spatial GMM } \\
\text { Est. } \\
\text { (Cutoff }=0.5)\end{array}$ & $\begin{array}{c}\text { Spatial GMM } \\
\text { SE } \\
\text { (Cutoff }=0.5 \text { ) }\end{array}$ \\
\hline Intercept & -.95503801 & .15016687 & -.9338026 & .21124536 \\
\hline In Wage in 1991 & .19092101 & .0156507 & .18901078 & .02148466 \\
\hline In 5 to 15 over 15 to 55 yrs Ratio & .1983383 & .03620152 & .19401434 & .05055868 \\
\hline Proportion of Natives in 1991 & .28972116 & .04454679 & .3009288 & .06903289 \\
\hline Delta In Market Potential & .30840242 & .03091629 & .30340591 & .05130368 \\
\hline In Teacher Qualification in 1991 & -.00807114 & .00235408 & -.00812438 & .00351447 \\
\hline Homicides in 1991 & -6.9250641 & 4.325995 & -8.436305 & 11.13018 \\
\hline Employment in Farming in 1991 & -.46696147 & .16523983 & -.50415081 & .25446269 \\
\hline Bank Dummy & .00072828 & .00950343 & .00397452 & .01257344 \\
\hline In Population in 1991 & -.02531787 & .00636568 & -.02616172 & .00975625 \\
\hline Mean Temperature & -.00678719 & .00265857 & -.00660142 & .00409379 \\
\hline Total Rainfall & -.00005046 & .00001317 & -.00004882 & .00002093 \\
\hline Rainfall - $1^{\circ}$ Princ. Component & .00971466 & .00196289 & .00973935 & .00324289 \\
\hline Rainfall - 3ํP Princ. Component & .02245587 & .00465159 & .02228627 & .00712442 \\
\hline Employment rate in 1991 & .15742175 & .14161712 & .17703837 & .2183038 \\
\hline crit. fn. test of overid. restrictions & --- & $-\overline{--}$ & 3.819309 & 3.819309 \\
\hline $\begin{array}{l}\text { Dependent Variable: } \\
\text { Delta In Employment }\end{array}$ & $\begin{array}{c}\text { Spatial GMM } \\
\text { Est. } \\
(\text { Cutoff }=1)\end{array}$ & $\begin{array}{c}\text { Spatial GMM } \\
\text { SE } \\
\text { (Cutoff }=1\end{array}$ & $\begin{array}{l}\text { Spatial GMM } \\
\text { Est. } \\
(\text { Cutoff }=2)\end{array}$ & $\begin{array}{c}\text { Spatial GMM } \\
\text { SE } \\
(\text { Cutoff }=2)\end{array}$ \\
\hline Intercept & -.91925794 & .23347463 & -.8959102 & .25081733 \\
\hline In Wage in 1991 & .18708293 & .02332669 & .183212 & .0248753 \\
\hline In 5 to 15 over 15 to 55 yrs Ratio & .19600923 & .05612046 & .19536939 & .06081697 \\
\hline Proportion of Natives in 1991 & .30085957 & .07981306 & .29273868 & .09316006 \\
\hline Delta In Market Potential & .30237946 & .05999995 & .30237827 & .06949838 \\
\hline In Teacher Qualification in 1991 & -.008132 & .00415266 & -.0078909 & .0047722 \\
\hline Homicides in 1991 & -9.6619034 & 15.947038 & -12.576632 & 24.664917 \\
\hline Employment in Farming in 1991 & -.52499872 & .29569033 & -.53298384 & .3420592 \\
\hline Bank Dummy & .00465381 & .01249154 & .00546396 & .01298614 \\
\hline In Population in 1991 & -.02584312 & .01101769 & -.02346004 & .01342835 \\
\hline Mean Temperature & -.006529 & .00497929 & -.00703587 & .00608096 \\
\hline Total Rainfall & -.00004341 & .0000258 & -.00003918 & .00003218 \\
\hline Rainfall - $1^{\circ}$ Princ. Component & .00924989 & .00368997 & .00853621 & .00395734 \\
\hline Rainfall - $3^{\circ}$ Princ. Component & .02213984 & .00880441 & .02222459 & .01032099 \\
\hline Employment rate in 1991 & .18801478 & .2473453 & .18705417 & .27703223 \\
\hline crit. fn. test of overid. restrictions & 3.0782778 & 3.0782778 & 2.4566422 & 2.4566422 \\
\hline
\end{tabular}




\section{Labor Market Dynamics}
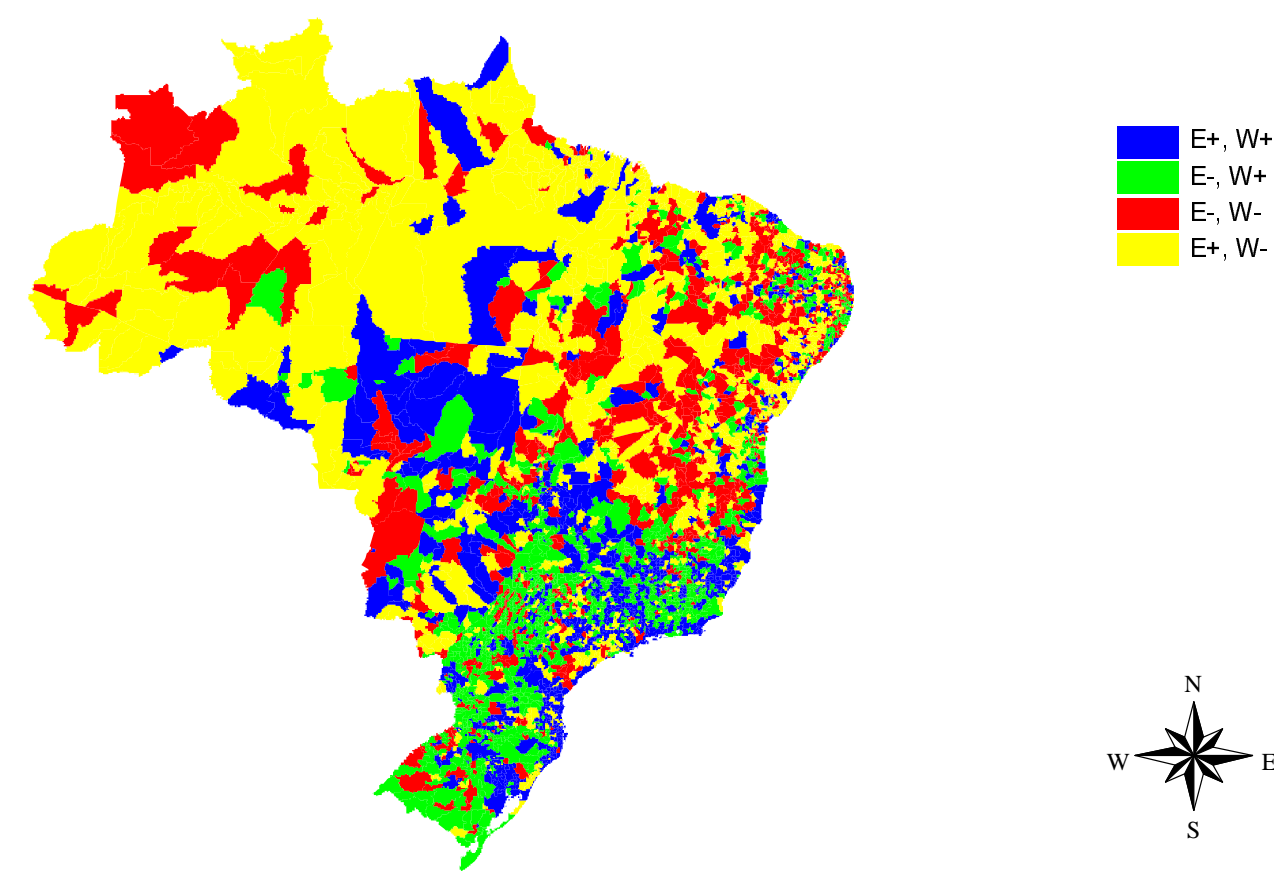

900

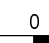

900

1800 Miles

Figure 1 Labor dynamics, Brazil

Categorization of MCA by its labor dynamics

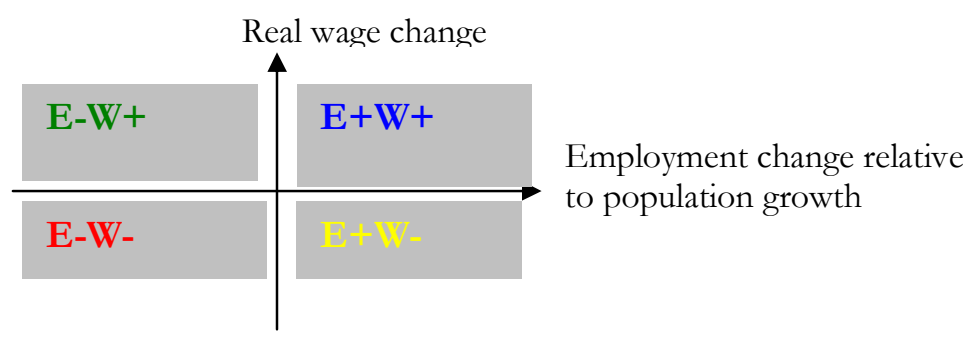




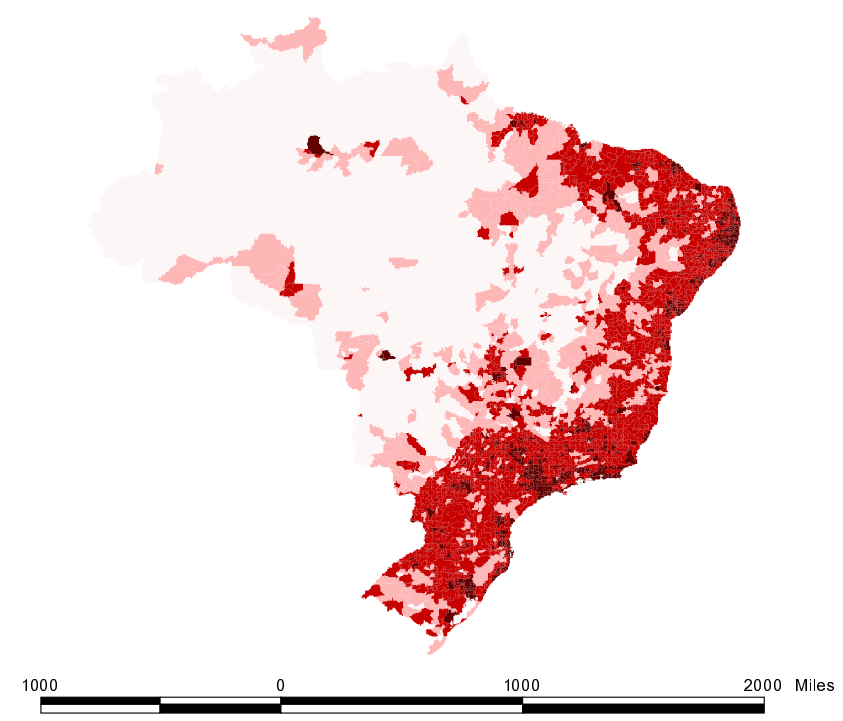

Population Density 2000 $0.131-3.816$

$3.816-12.225$

$12.225-85.984$

$85.984-12878.968$

$\underbrace{N}_{S}$

Figure 2 Population density, 2000 
Population distribution by region and labor market outcome

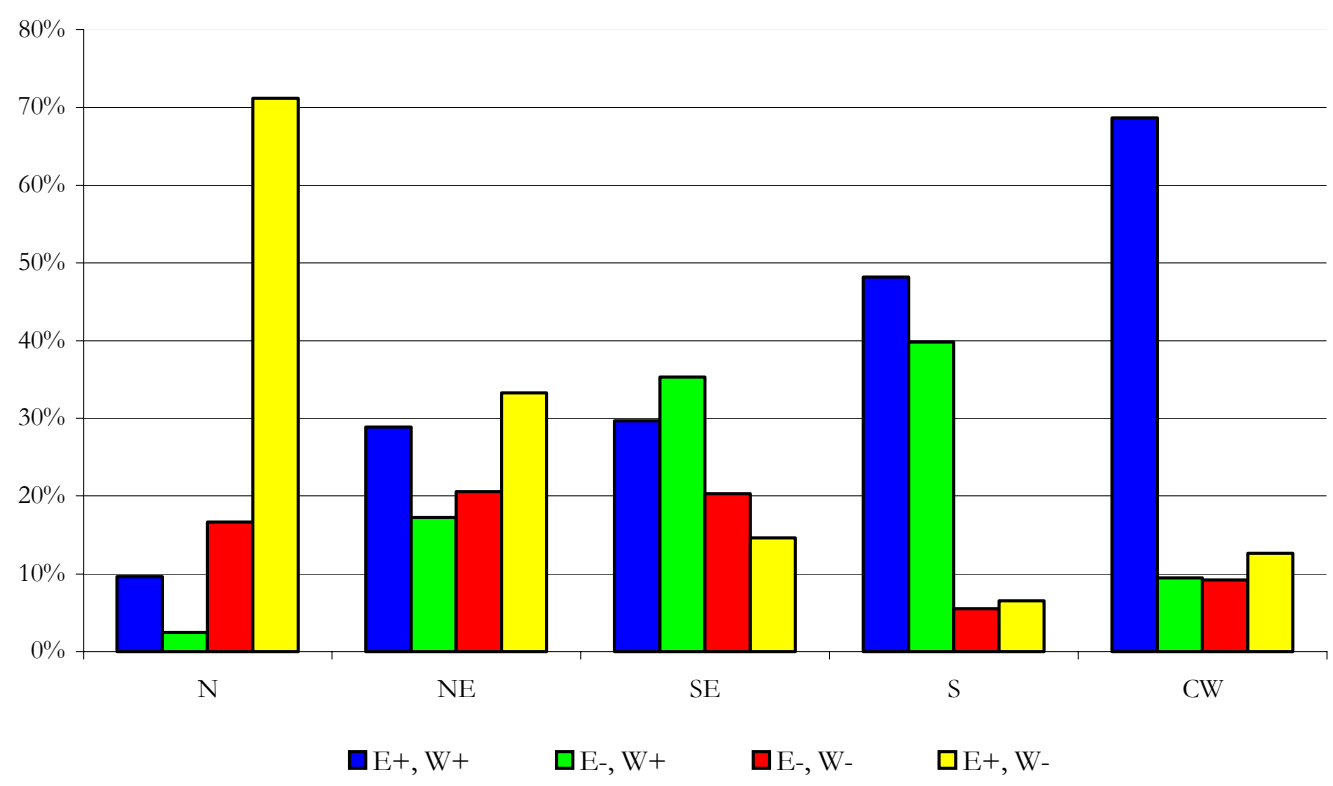

Figure 3 Population distribution by region and labor market outcome 


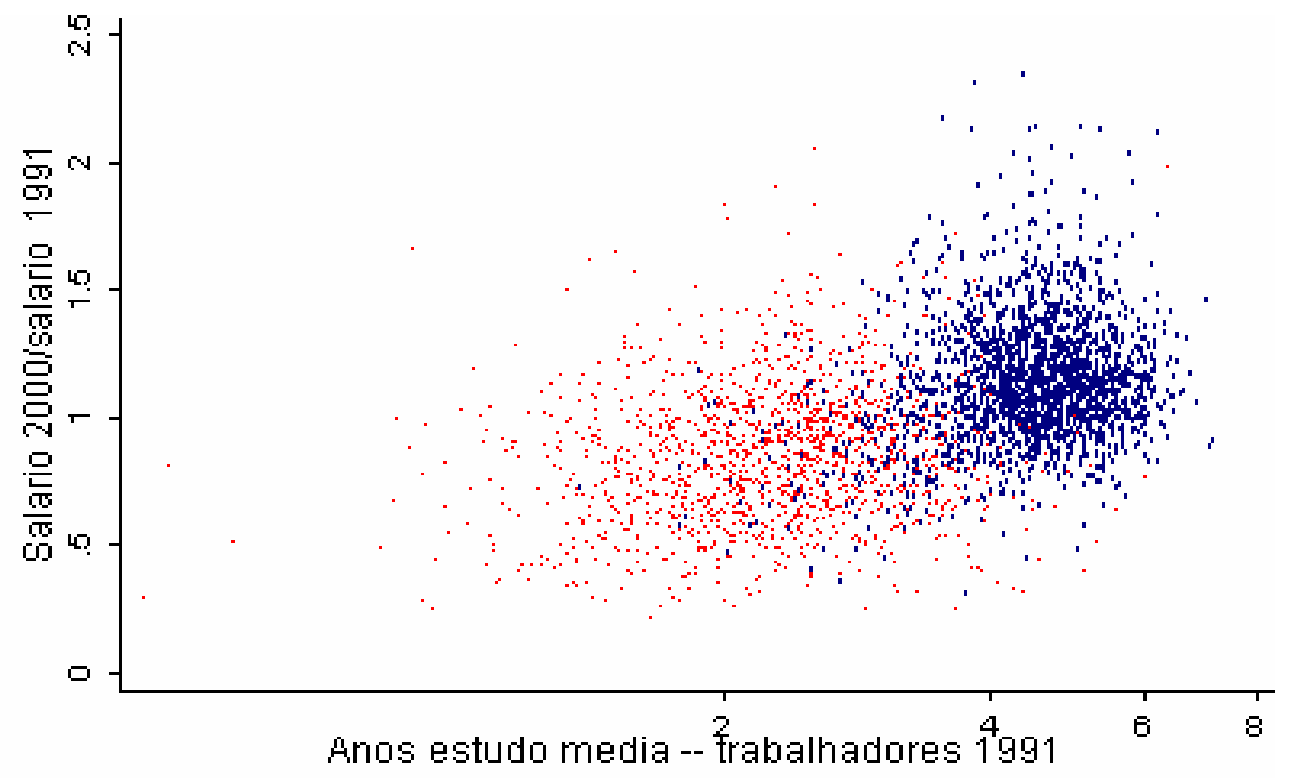

Figure 4 Worker education vs. wage growth

Red - North and Northeast Regions.

Blue - Southeast, South and Center-West Regions. 


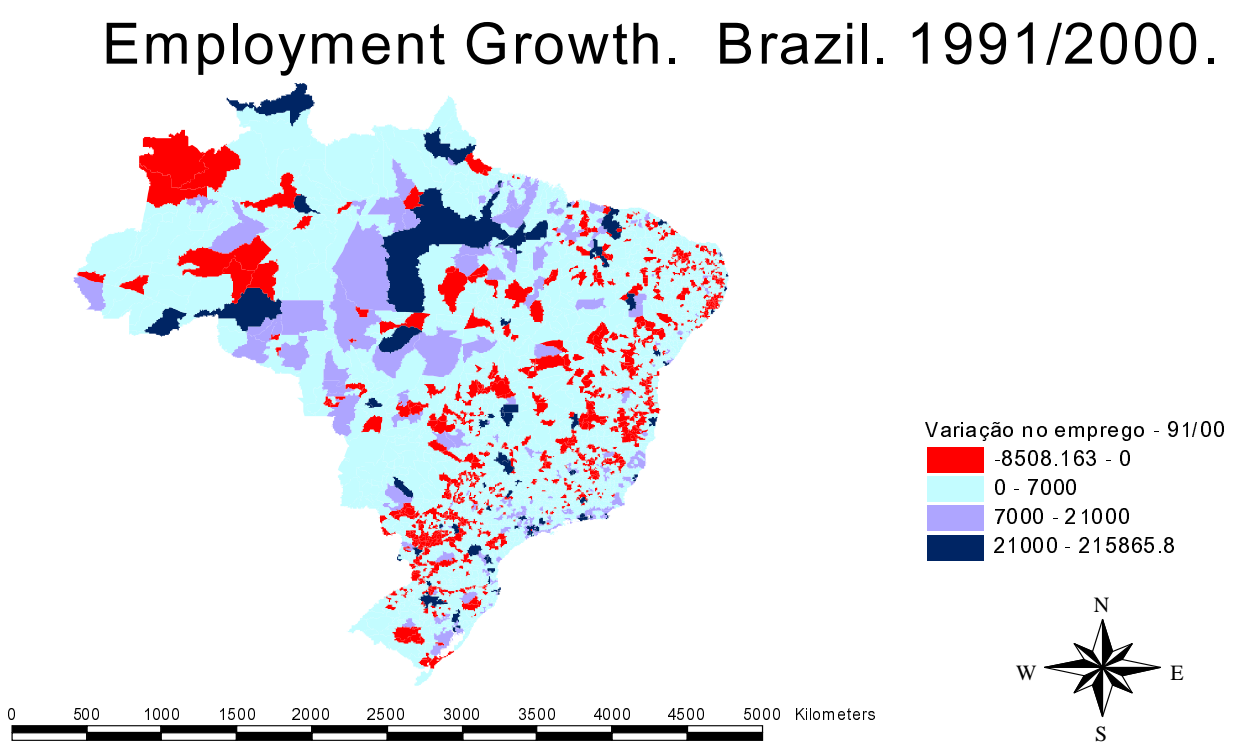

Map 1 

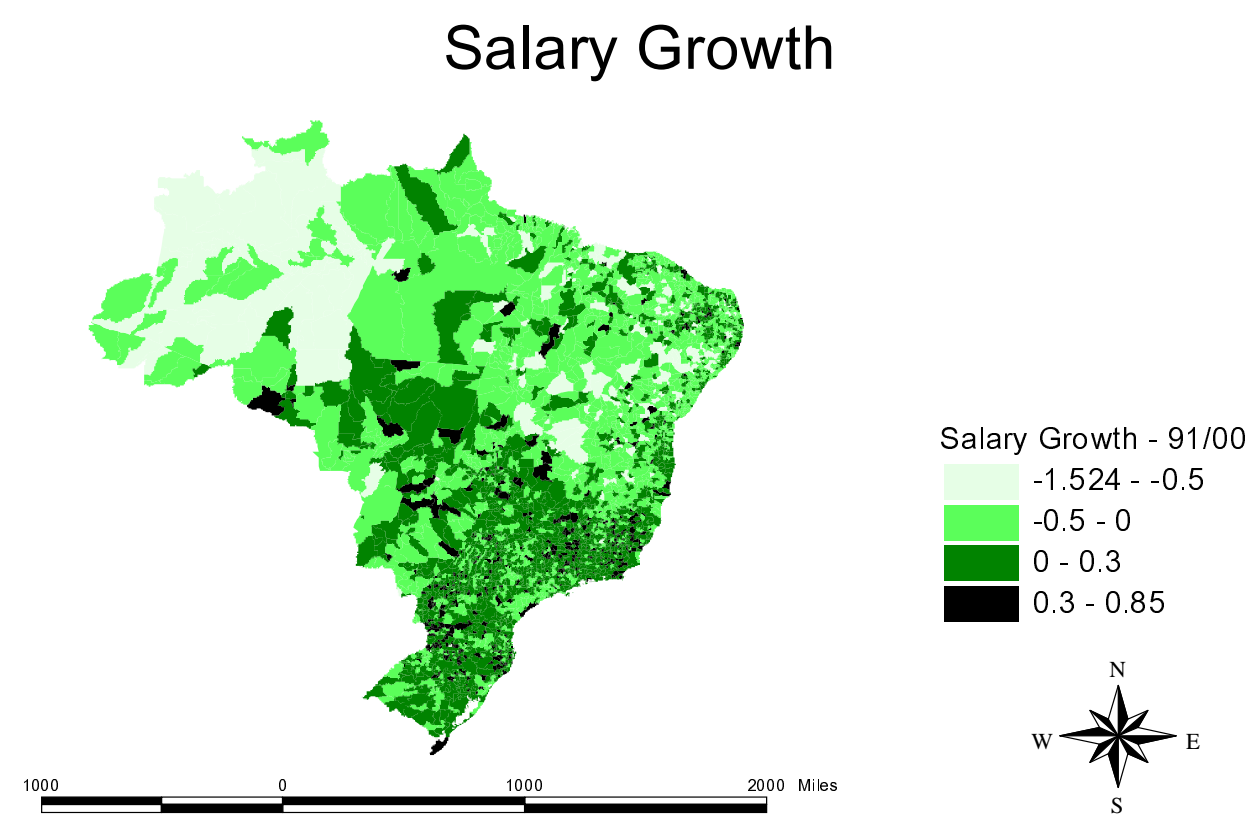

Map 2
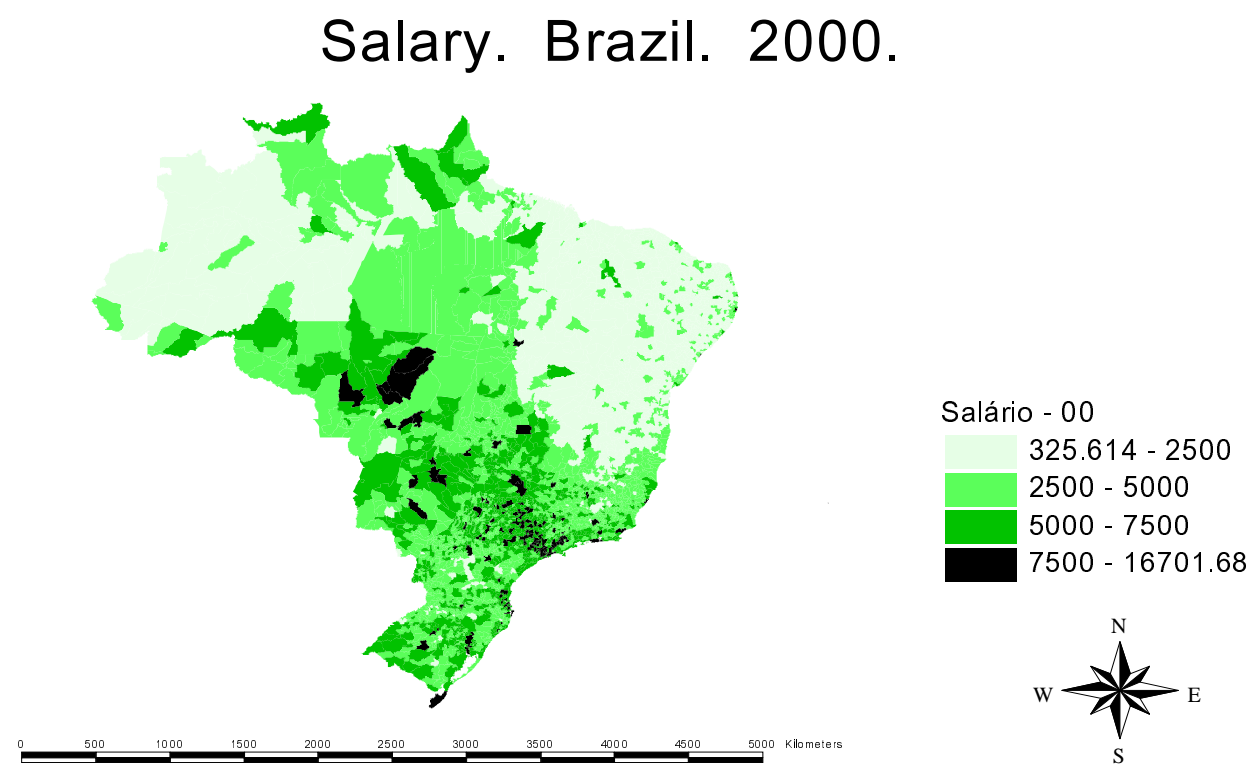

Map 3 


\section{Years of study growth $-1991 / 2000$}

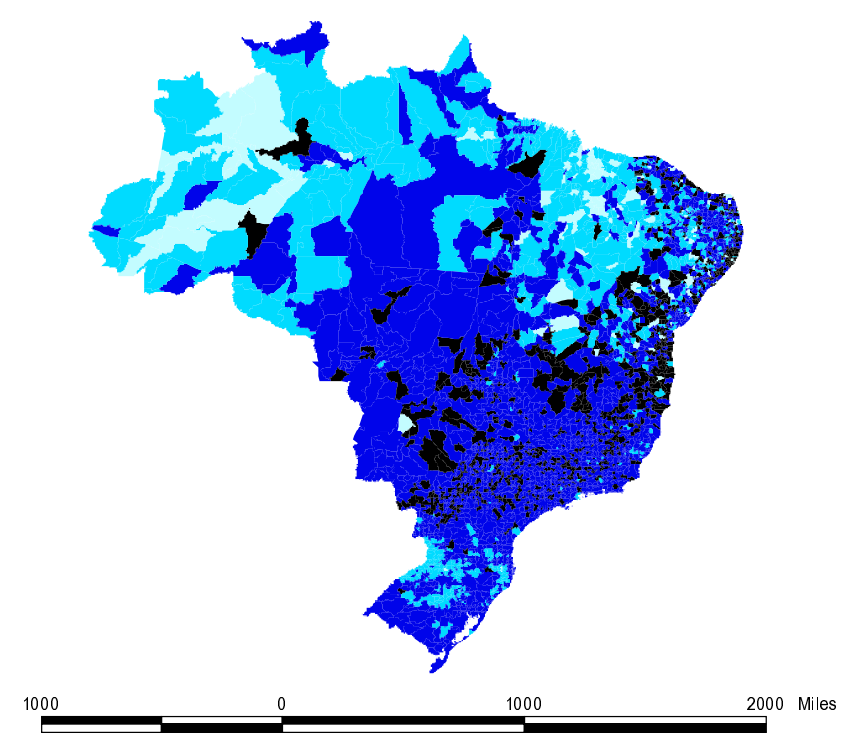

Years of study growth $-91 / 00$ $-3.739--0.5$

$-0.5-0$

$0-0.3$

$0.3-1.245$

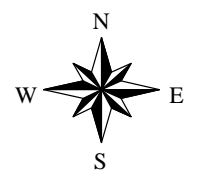

Map 4

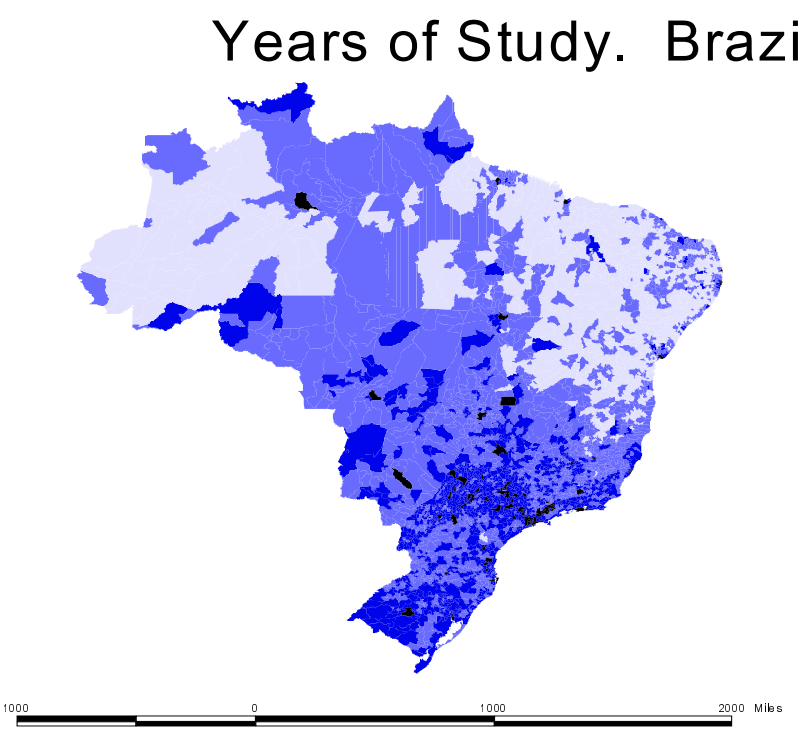

Anos de estudo - 00

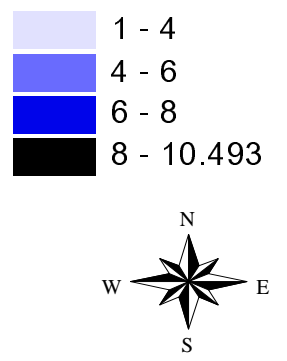

Map 5 
Teacher Qualification Growth. Brazil. 1991/2000.
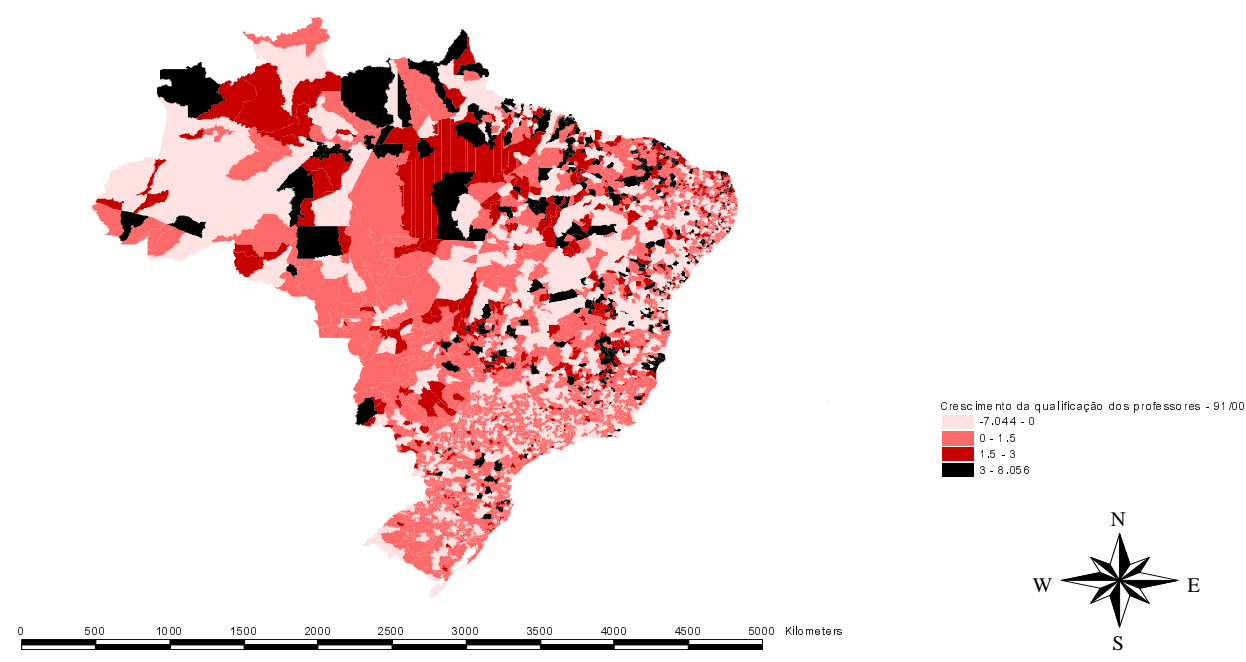

Map 6

Percentage of income from government transferences. Brazil. 2000
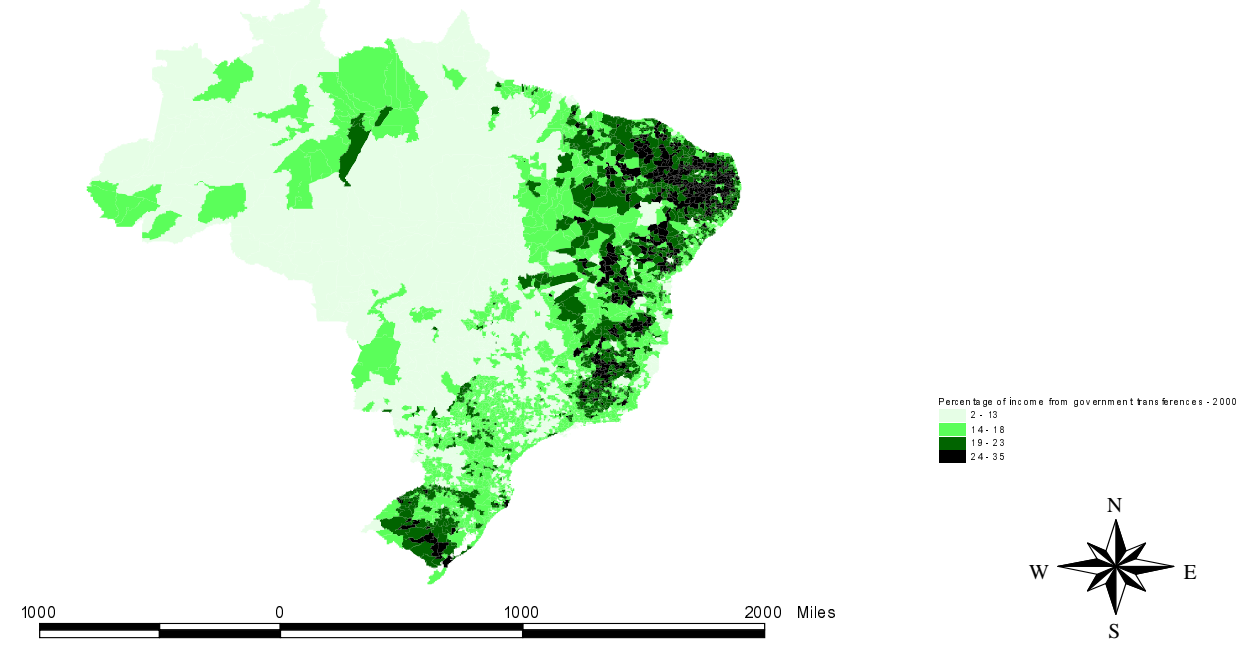

Map 7 
Changes in transport costs to capital. 1995/1980

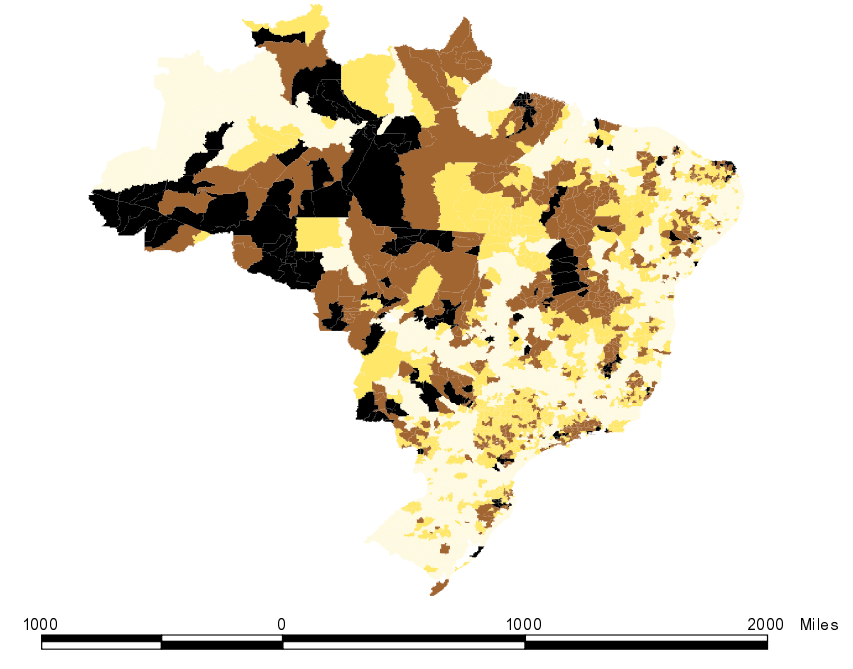

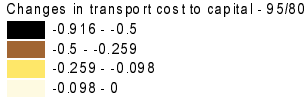

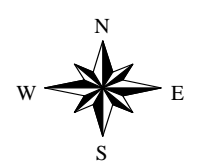

Map 8

Change in transport cost to SP. $1995 / 1980$
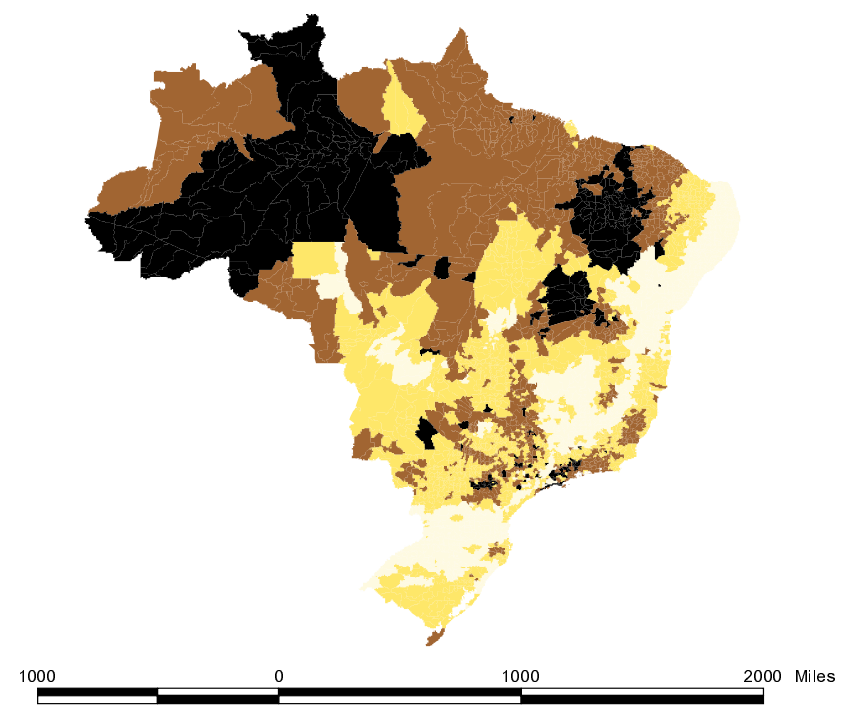

Changes in transport cost to SP - 95/80 $-0.916--0.331$
$-0.331--0.197$ $-0.197--0.087$ $-0.087-0$

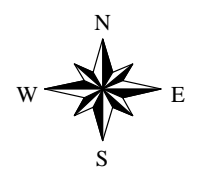

Map 9 


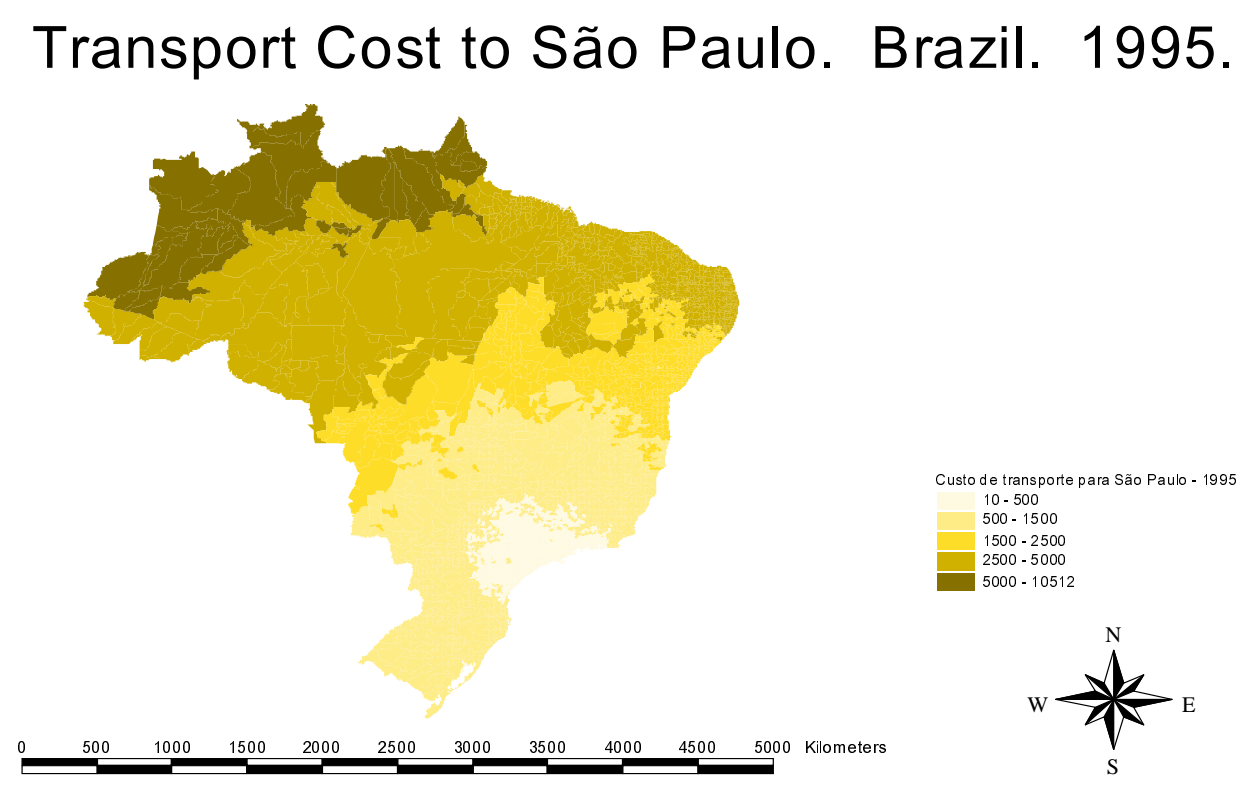

Transport Cost to Capital. Brazil. 1995.

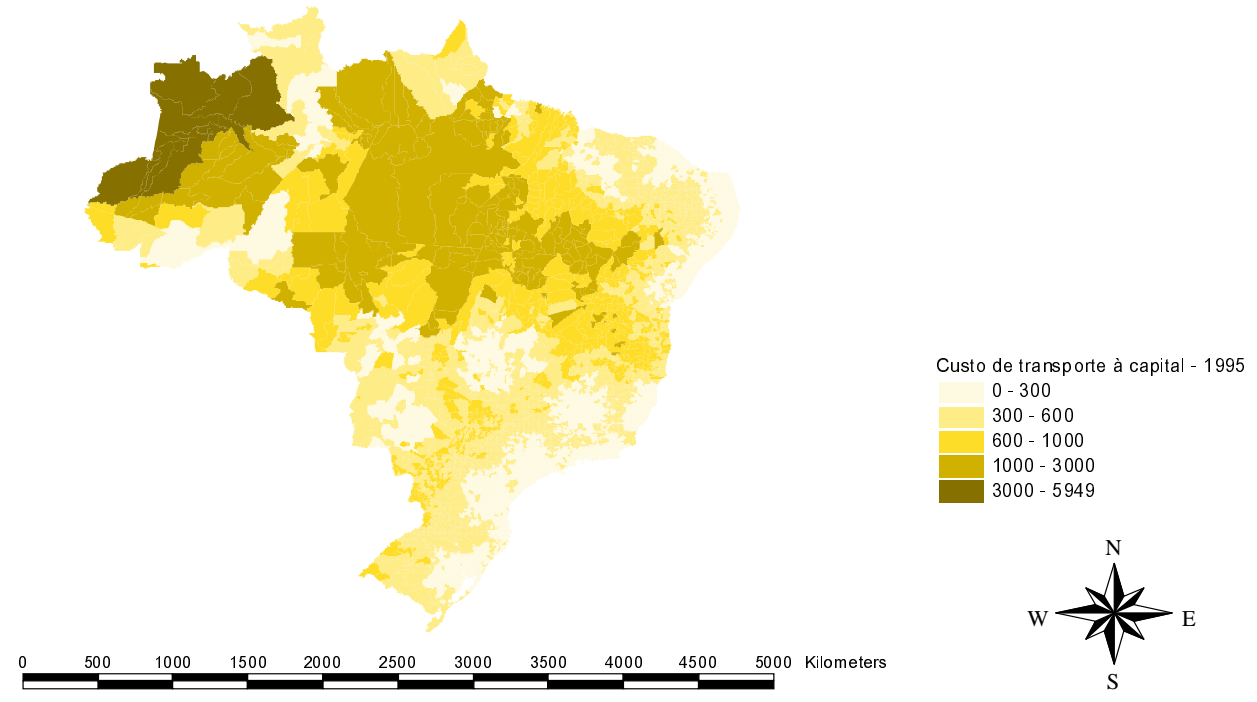

Map 10 
Government accountability in computers. 1999
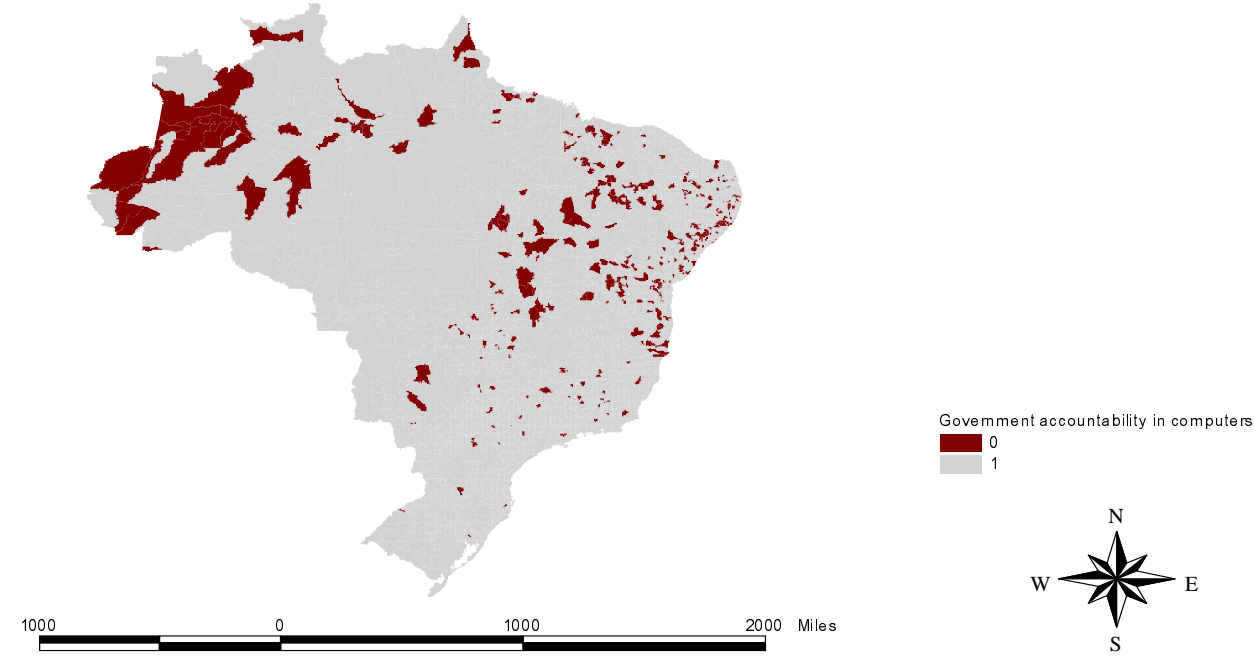

Map 11

Market Potential. Brazil. 2000.
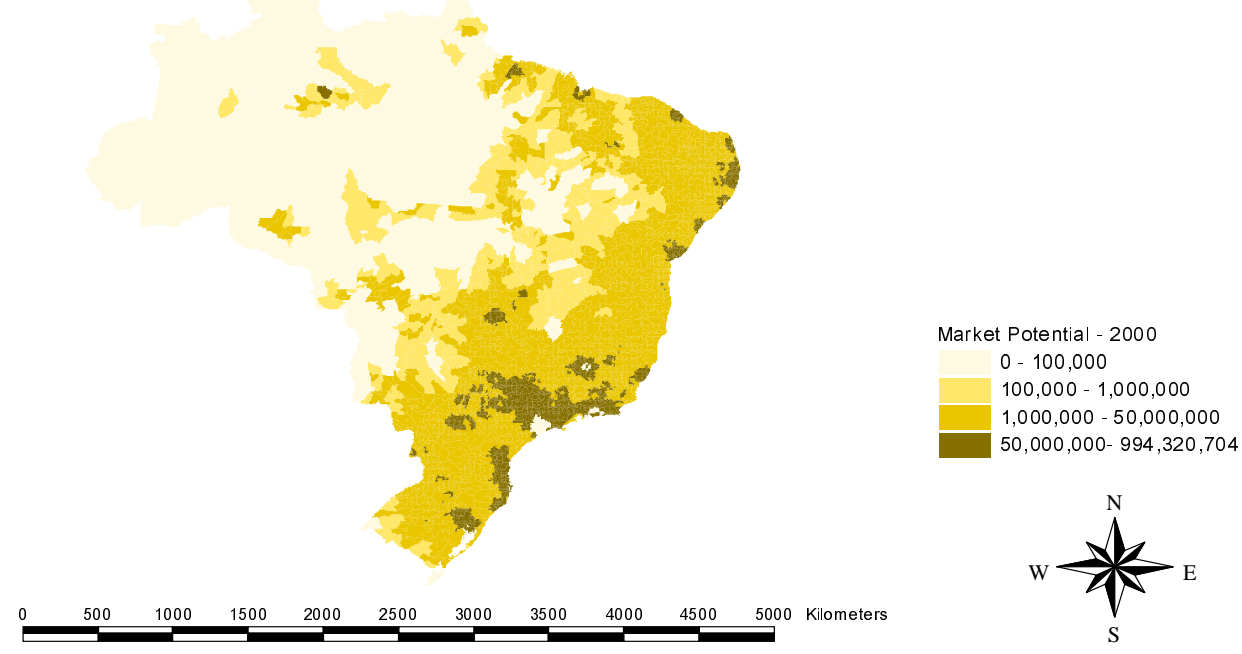

Map 12 